\title{
QUEEN'S
UNIVERSITY
BELFAST
}

\section{End-of-Life Alternatives for Wind Turbine Blades: Sustainability Indices Based on the UN Sustainable Development Goals}

Deeney, P., Nagle, A., Gough, F., Lemmertz, H., Delaney, E., McKinley, J., Graham, C., Leahy, P., Dunphy, N., \& Mullally, G. (2021). End-of-Life Alternatives for Wind Turbine Blades: Sustainability Indices Based on the UN Sustainable Development Goals. Resources, Conservation and Recycling, 171, [105642]. https://doi.org/10.1016/j.resconrec.2021.105642

Published in:

Resources, Conservation and Recycling

Document Version:

Publisher's PDF, also known as Version of record

Queen's University Belfast - Research Portal:

Link to publication record in Queen's University Belfast Research Portal

Publisher rights

(C) 2021 The Authors

This is an open access article published under a Creative Commons Attribution License (https://creativecommons.org/licenses/by/4.0/), which permits unrestricted use, distribution and reproduction in any medium, provided the author and source are cited.

\section{General rights}

Copyright for the publications made accessible via the Queen's University Belfast Research Portal is retained by the author(s) and / or other copyright owners and it is a condition of accessing these publications that users recognise and abide by the legal requirements associated with these rights.

Take down policy

The Research Portal is Queen's institutional repository that provides access to Queen's research output. Every effort has been made to ensure that content in the Research Portal does not infringe any person's rights, or applicable UK laws. If you discover content in the Research Portal that you believe breaches copyright or violates any law, please contact openaccess@qub.ac.uk. 
Full length article

\title{
End-of-Life alternatives for wind turbine blades: Sustainability Indices based on the UN sustainable development goals
}

\author{
Peter Deeney ${ }^{\mathrm{a}, \mathrm{b}, \mathrm{g}, *}$, Angela J. Nagle ${ }^{\mathrm{a}, \mathrm{b}}$, Fergal Gough ${ }^{\mathrm{a}, \mathrm{c}}$, Heloisa Lemmertz ${ }^{\mathrm{a}, \mathrm{c}}$, \\ Emma L. Delaney ${ }^{\mathrm{d}}$, Jennifer M. McKinley ${ }^{\mathrm{d}}$, Conor Graham ${ }^{\mathrm{d}}$, Paul G. Leahy ${ }^{\mathrm{a}, \mathrm{b}, \mathrm{g}}$, Niall \\ P. Dunphy ${ }^{\mathrm{a}, \mathrm{b}, \mathrm{e}, \mathrm{g}}$, Gerard Mullally ${ }^{\mathrm{a}, \mathrm{c}, \mathrm{e}, \mathrm{f}, \mathrm{g}}$ \\ ${ }^{a}$ Environmental Research Institute, University College Cork, Lee Road, Cork, Ireland \\ ${ }^{\mathrm{b}}$ School of Engineering and Architecture, University College Cork, College Road, Cork, Ireland \\ ${ }^{\mathrm{c}}$ Department of Sociology and Criminology, University College Cork, Donovan's Road, Cork, Ireland \\ ${ }^{\mathrm{d}}$ School of Natural and Built Environment, Queen's University Belfast, Elmwood Avenue, Belfast, Northern Ireland, UK \\ e Cleaner Production Promotion Unit, University College Cork, Lee Road, Cork, Ireland \\ ${ }^{\mathrm{f}}$ Institute for Social Science in the 21st Century (ISS21), University College Cork, Donovan's Road, Ireland \\ ${ }^{\mathrm{g}}$ MaREI SFI Research Centre for Energy, Climate and Marine, University College Cork, Ringaskiddy, Co. Cork, Ireland
}

\section{A R T I C L E I N F O}

\section{Keywords:}

Composite Recycling

Glass Fibre Reinforced Polymer (GFRP) Delphi Study

Multiple Criteria Decision Analysis (MCDA)

Life Cycle Assessment (LCA)

Geographic Information Science (GIS)

\begin{abstract}
A B S T R A C T
The background to this research is that across the world there will be 200,000 tonnes of wind turbine blade waste to be disposed of each year from 2033. The purpose of the research is to compare the relative sustainability of alternative ways to deal with this waste, these being: landfill, incineration with heat recovery, co-processing in cement kilns, making furniture and bridge fabrication. The method is to use the UN Sustainable Development Goals (SDGs) to select 11 metrics for sustainability. The use of the SDGs adds to the objectivity of this process overcoming one of the principal weaknesses of Multiple Criteria Decision Analysis (MCDA). Quantitative information methods from Life Cycle Assessment, Geographic Information Science, census data and real options analysis of R\&D, alongside qualitative information from Delphi studies and Strengths/Weaknesses/Opportunities/Threats analysis are combined in the assessment. Three MCDA methods are used, each calculates economic, social and environmental sustainability indices for the end-of-life alternatives which are then combined into integrated sustainability indices. A novel Delphi stopping condition based on consensus, consistency and convergence is used. The primary result is that bridge fabrication is the most sustainable alternative with furniture making in second place. Co-processing, incineration with heat recovery and landfill are progressively less sustainable alternatives. This result is robust to substantial changes in the selection of experts' opinions, the weights for MCDA and the values of the metrics. These findings offer researchers and policymakers a robust decision making process, applicable to situations where choices are made on sustainability criteria.
\end{abstract}

\section{Introduction}

The use of wind turbines to generate electricity is expanding rapidly across the world (Lefeuvre et al., 2019). Figures from the International Energy Agency put wind generation at 1265 TWh in 2018 and project a rise to 3317 TWh or more by 2030 (IEA, 2019b). While this is good news from a sustainability point of view, there is a problem when wind turbines are decommissioned. Most of the components of wind turbines can be recycled easily, except for the blades which are of composite construction and normally contain a very high proportion of glass fibre reinforced polymer (GFRP) or carbon fibre reinforced polymer (CFRP) (Cherrington et al., 2012; Beauson et al., 2016; Tazi et al., 2019) ${ }^{1}$.

It is expected that globally, there will be 100,000 tonnes of blade waste produced annually in 2025 and 200,000 tonnes by 2033 (Beauson and Brøndsted, 2016). This problem will continue for at least the next 20 - 25 years (the typical life span of wind turbines). While this is

\footnotetext{
* Corresponding author.

E-mail addresses: peter.deeney@ucc.ie, peter.deeney2@mail.dcu.ie (P. Deeney).

${ }^{1}$ Since CFRP is a relatively new material for blade construction, it is not expected to enter the waste stream for several years, hence this investigation will consider GFRP.
} 
happening, more wind power is expected to be installed across the world over the next decades rising from the existing installed capacity of 650 GW (WWEA, 2021) to over 2015 GW by 2030 (IRENA, 2019). Each GW of installed capacity requires approximately 10,000 tonnes of blade material (Bank, Arias, et al., 2018; Jensen and Skelton, 2018).

The existing literature on wind turbine blades at end-of-life, focuses on methods to recycle the composite material in the blades, there are only rare examples of research into the reuse of blades (Bank, Arias, et al., 2018; Bank et al., 2019; Joustra et al., 2021). Of the recent literature Liu et al. (2019) compares the energy use of landfill, incineration, mechanical recycling and pyrolysis but does not consider re-use. Chiesura et al. (2020) looks at LCA of wind blades and finds that it is the extraction of the materials which accounts for the largest contribution to GHG emissions. The paper does not focus attention on direct reuse of the blade material at decommissioning. Murray et al. (2021) looks at thermoplastic turbine blades which could provide an easier route to reuse than the standard thermoset blades. Cooperman et al. (2021) looks at landfill, incineration, co-processing, mechanical recycling and design for recycling. This paper provides an interesting insight into the high cost of decommissioning blades but is not aimed at other ways of comparing the end of life choices for turbine blades. There is no example of a comparison of possible end-of-life blade choices which cover the range of alternatives from landfill, recovery of energy, recycling of material or reuse of blades, hence the need for the current research.

In practice there are two dominant end-of-life solutions at present: landfill and incineration (Jensen and Skelton, 2018; Liu et al., 2019). These two solutions are on the two lowest levels of the waste management priority list (landfill and recovery) required to build a circular economy (European Commission, 2008).

Landfill disposes of a large amount of blade waste very quickly, however it is at the bottom of the waste priority list of the EU Waste Framework Directive, (European Commission, 2008) and the waste hierarchy of the US EPA (EPA(USA), 2020). Landfill is an expedient way to dispose of blade waste where it is permitted, but Germany, Austria and Finland have already banned wind blades from landfills. The Netherlands has banned composite waste from landfill in principle, if not in practice (Cherrington et al., 2012; WindEurope, 2020) and other European countries will probably follow (Jacob, 2011). Some landfill operators in the USA are now refusing blade waste (personal communication with Lawrence C. Bank, 5th August 2020). Landfill is permitted in the UK and in Ireland where the prices range from Stg£48 (€54) per tonne in the UK to $€ 113$ per tonne in Ireland. The fee charged by operators in Ireland for landfill is likely to increase as the Irish government landfill levy has risen from $€ 30$ per tonne in 2010 to $€ 75$ per tonne in 2013, (EPA(Ireland), 2020). There are suggestions that this levy may increase to $€ 80$ per tonne (DCCAE, 2019).

Incineration has the advantage that it can produce heat and power, and therefore recovers some of the energy in the blades, but it still relies on landfill to dispose of the ash. Incineration is the principal alternative to landfill for wind turbine blade disposal in Europe (WindEurope, 2020). Heat recovery offers the possibility of some positive environmental outcomes. This is because the extraction of 6 tonnes of coal used for heat or power production can be avoided by using 10 tonnes of blade waste (Liu et al., 2019; Nagle et al., 2020).

Other alternatives for the blades after decommissioning include coprocessing the GFRP in a cement kiln to produce cement (Nagle et al., 2020) as well as furniture making and bridge fabrication (Bank, Arias, et al., 2018; Suhail et al., 2019). Co-processing of wind blades, which is a form of recycling, involves adding wind blades to other feedstock in a cement kiln, thereby substituting some of the virgin raw material required for cement manufacture. Co-processing allows all of the blade material to be fully used up in the cement kiln. The carbon polymer in the GFRP substitutes some fuel, and the glass fibre substitutes some cement raw ingredients ( $\mathrm{Si}$, lime in some cases, iron oxide) (Nagle et al., 2020). The only operator in Europe offering co-processing at present is Neocomp in conjunction with the Holcim Cement Factory in Lägerdorf,

\section{Germany.}

Repurposing the blades to use them to make valuable products is higher up the waste priority list. Since blades are made of hard, strong and weather-resistant material, there are numerous possible uses for them. For example, they can be used for doors, windows or roofs (Bank, Arias, et al., 2018), bridges, playgrounds or urban furniture (Jensen and Skelton, 2018; SuperUse, 2020), interior furniture (Bladesign, 2020), building materials (Jensen and Skelton, 2018) or sound insulation materials (Winddemark, 2019; Miljøskærm, 2020). Using blades to make furniture is a very recent development in Germany (Bladesign, 2020), Denmark (Winddemark, 2019) and Poland (Webber, 2020).

Bridge fabrication is another re-purposing alternative. A short span pedestrian bridge is described by Suhail et al. (2019). Greenways are ideal locations for short span bridges, these are pedestrian/cycle paths which are becoming more popular as governments across Europe invest in low carbon transport.

There are of course many other choices for the end of a blade's life, but the five alternatives above are a selection across the, disposal -recover - recycle - repurpose range of priorities from the Waste Directive (European Commission, 2008). The assessment of the sustainability of these and other alternatives is a complex matter (Van Schoubroeck et al., 2019). To carry out such an assessment it is necessary to select which aspects of sustainability should be measured, by which metrics, and how to combine these metrics to produce an assessment of sustainability.

There are several multiple criteria decision analysis (MCDA) methods to combine sustainability metrics. The effectiveness of MCDA for complex assessments has been established in the literature (Zanakis et al., 1998; Pohekar and Ramachandran, 2004; Chen et al., 2013; Jayaraman et al., 2015; Delvere et al., 2019; Sassanelli et al., 2019). Amongst the MCDA methods, Analytical Hierarchy Process (AHP) is the most frequently used method (Pohekar and Ramachandran, 2004; Liu et al., 2011; Diamond et al., 2014). AHP has been used by Chen et al. (2013); Kim et al. (2013); Ghobadi and Ahmadipari, (2018), who applied it to electronic waste management, industrial site selection and land use selection. Another MCDA method, Preference Ranking Organization Method for Enrichment Evaluation (PROMETHEE) has been used by Behzadian et al. (2010); Vavatsikos et al., (2020) who applied it to planning decisions, business management and energy management. A third MCDA method is ELimination Et Choix Traduisant la REalité (ELECTRE) which has been used by Almeida, (2007); Wang and Triantaphyllou, (2008); Govindan and Jepsen, (2016) applied to contract selection, solid waste management system, water resources, information technology, natural resources and environmental management. The use of MCDA in the context of wind energy has thus far been limited to siting, design and investment decisions (Mardani et al., 2015; Strantzali and Aravossis, 2016) rather than disposal challenges.

This investigation proposes a wide and objective approach to create Economic, Social and Environmental Sustainability Indices to compare the five alternatives above. An Integrated Sustainability Index (SI) is proposed which combines the three fundamental dimensions of economic, social and environmental sustainability. The first contribution to the literature, is the use of the UN Sustainable Development Goals (UN SDGs) as a starting point for metric selection. This step ensures that the metrics are chosen fairly and objectively, it offers a correction to the subjectivity problems of MCDA methods mentioned by Chang et al. (2008); Zavadskas et al. (2018); Park et al. (2020). To further verify the fairness of the comparison between the five alternatives, three MCDA methods AHP (Saaty, 2002), PROMETHE (Brans et al., 1984) and ELECTRE (Roy, 1968) are used to ensure that the results from the analysis are not dependant on the particular MCDA method used. A second contribution is the application of MCDA to blade waste management. A final contribution is a joint consensus, consistency and convergence test as a stopping condition for Delphi Studies which have been used in this investigation.

The next section contains a discussion of the selection of the metrics 


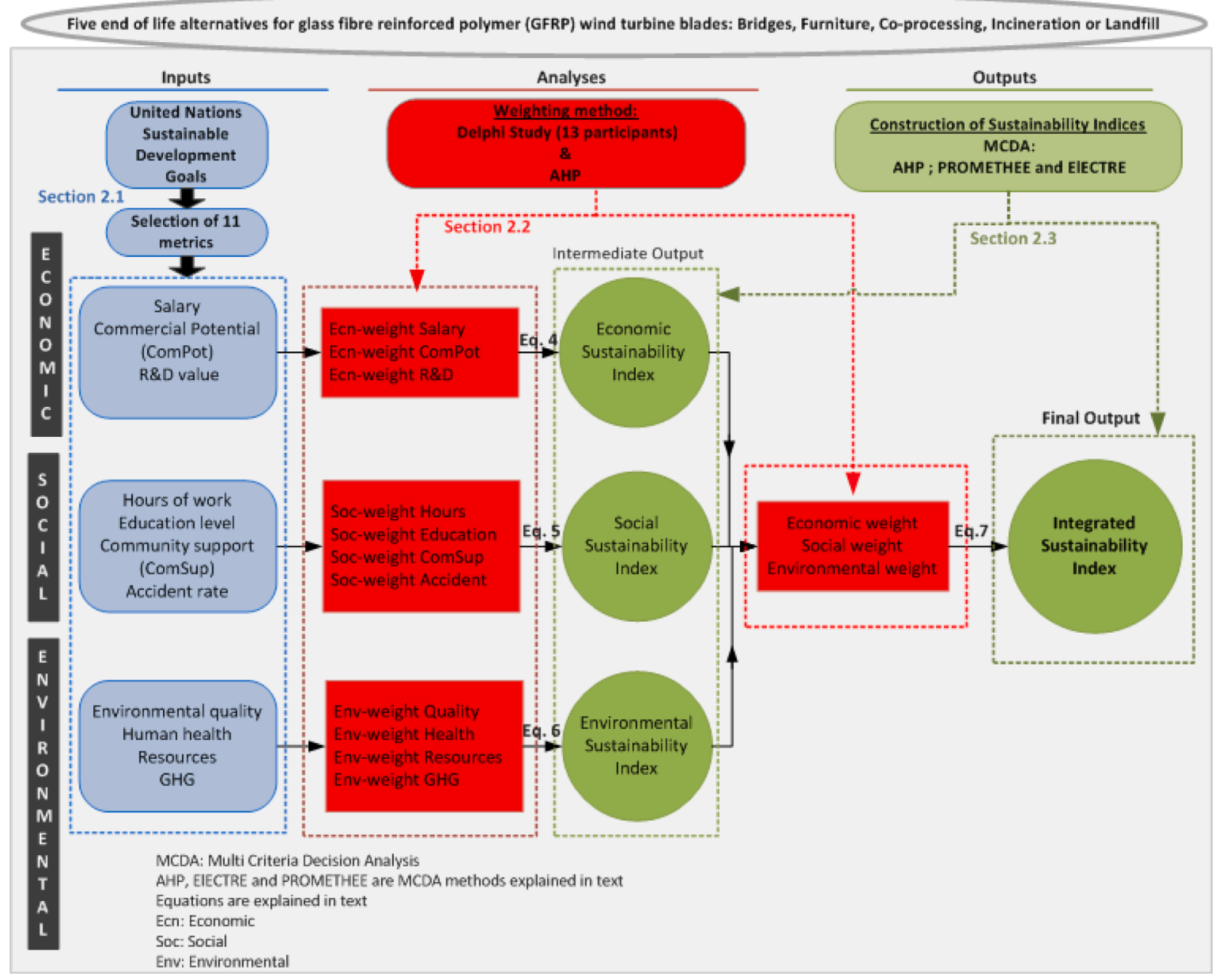

Fig. 1. Overview of Methodology.

based on the UN SDGs, the data, the Delphi Studies which determine the weights for the MCDA and the construction of the Sustainability Indices. The results are in Section 3 which includes an extensive sensitivity analysis and a discussion of the significance of the findings. Section 4 concludes.

\section{Methodology}

This investigation proposes the use of MCDA methods to create sustainability indices applied to the end-of-life alternatives for wind blades, based on the UN SDGs. The MCDA methods will create indices for the three dimensions of economic, social and environmental sustainability and combine these to achieve an integrated perspective. The overall methodology is laid out in Fig. 1.

The metrics selected from the UN SDGs (UN, 2015) on the left in Fig. 1, measure different aspects of the sustainability of five end-of-life alternatives for decommissioned wind turbine blades (see Section 2.1). A Delphi study using an AHP method (Saaty, 2008) creates four sets of weights (red boxes in Fig. 1), three of these sets compare the relative importance of the input metrics for each of the economic, social and environmental sustainability dimensions, the fourth set compares the relative importance of these dimensions with each other. The first three sets of weights are used to produce sustainability indices for each of the dimensions, and the fourth set is used to combine these into an integrated index (see Section 2.2 for more details). The process of creating the indices is done by three MCDA methods: AHP, PROMETHEE and ELECTRE (green circles in Fig. 1) which are further explained in Section
2.3. The Integrated Sustainability Index from the AHP method is also used to produce a ternary plot to illustrate the sensitivity analysis. A further, more detailed, explanation of the methods and data is provided below.

\subsection{Metric selection based on UN SDGs}

The UN SDGs were the original sources for selecting the 11 input metrics in Fig. 1. The use of the SDGs and their indicators (IAEG-SDGs, 2016) is inspired by the need to measure sustainability in a comprehensive, objective and fair way. While the SDGs may be comprehensive, objective and fair, they were designed to inspire and measure sustainability at a national level, here they are used at the level of individual products in an industrial setting. It is therefore necessary to select metrics carefully with regard to their applicability to the setting and their ability to discriminate between the five end-of-life alternatives. The eleven chosen metrics are grouped into the three dimensions of sustainability: economic, social and environmental and follow a similar pattern to Van Schoubroeck et al. (2019)

It is not possible to define the SDGs as being distinctly economic, social or environmental in character (Elkington, 1994; Horan, 2020) as there is no consistent way to separate the SDGs into three distinct groups. For instance, (Costanza et al., 2016; Barbier and Burgess, 2017; Scherer et al., 2018) and (Clark et al., 2020) disagree on how to categorize SDGs $1,2,3,6,7,11$ and 12 . In this investigation, the grouping of the UN SDGs into three sustainability dimensions is done at the metric level as summarized in Table 1. While the social and environmental 
Table 1

Summary of Metrics, their origins from the SDGs, brief descriptions and values.

\begin{tabular}{|c|c|c|c|c|c|c|c|c|}
\hline \multirow[t]{2}{*}{ Metrics } & \multirow{2}{*}{$\begin{array}{l}\text { Based on SDG } \\
(s)^{1}\end{array}$} & \multirow[t]{2}{*}{ Description } & \multirow[t]{2}{*}{ Source } & \multicolumn{5}{|c|}{ Values of the input metrics (Section 2.1.2) } \\
\hline & & & & Landfill & Incineration & $\begin{array}{l}\text { Co- } \\
\text { Processing }\end{array}$ & Furniture & Bridge \\
\hline \multicolumn{9}{|l|}{ Economic } \\
\hline Salary $€$ & $\begin{array}{l}1,2,3,8,10 \\
11\end{array}$ & $\begin{array}{l}\text { Mean salary for work on one tonne of } \\
\text { blade waste }\end{array}$ & $\begin{array}{l}\text { Central Statistics } \\
\text { Office }\end{array}$ & 31.8 & 44.4 & 88.6 & 486 & 498 \\
\hline $\begin{array}{c}\text { Commercial } \\
\text { Potential }\end{array}$ & 8,9 & Estimation of future success & SWOT $^{2}$ Analysis & -1.67 & 0.667 & 2.17 & 4.33 & 1.67 \\
\hline$R \& D$ Valuation $€ m$ & 8,9 & Innovation potential & $\begin{array}{l}\text { Real Options } \\
\text { Analysis }\end{array}$ & 7 & 16 & 13 & 233 & 74 \\
\hline \multicolumn{9}{|l|}{ Social } \\
\hline Hours of Work & $1,2,3,8,9$ & $\begin{array}{l}\text { Hours of work for one tonne of blade } \\
\text { waste }\end{array}$ & Expert Opinion & 1.3 & 1.9 & 3.7 & 19.2 & 19.7 \\
\hline Education Level & 4,8 & Average Education Level & $\begin{array}{l}\text { Central Statistics } \\
\text { Office }\end{array}$ & 2.97 & 3.80 & 4.40 & 4.05 & 3.55 \\
\hline Community Support & 11,17 & Social support & Delphi Study & 0.03 & 0.05 & 0.12 & 0.39 & 0.41 \\
\hline Accident Rate & 8 & $\begin{array}{l}\text { Workplace accidents, injuries and } \\
\text { deaths }\end{array}$ & $\begin{array}{l}\text { Health \& Safety } \\
\text { Authority }\end{array}$ & 4 & 2 & 2 & 2 & 2 \\
\hline \multicolumn{9}{|l|}{ Environmental $^{3}$} \\
\hline Ecosystem Quality & $6,12,14,15$ & Aquatic and terrestrial eco-toxicity & LCA & 7.0 & 4.0 & -63.9 & -665.8 & -173.7 \\
\hline Human Health & 14,15 & Human toxicity & LCA & 0.00002 & -0.00002 & -0.0005 & -0.00126 & -0.00163 \\
\hline Resources & 7,12 & Non-renewable energy & LCA & 263.0 & -8421.2 & -9941.2 & $-10,051.8$ & $-30,944.2$ \\
\hline GHG & 7,13 & Net GHG emissions & LCA & 10.1 & -395.5 & -895.3 & -474.6 & -2620.1 \\
\hline
\end{tabular}

${ }^{1}$ Full list of SDGs and metrics are discussed in the Online Supplementary Files.

2 SWOT: Strengths, Weaknesses, Opportunities and Threats.

3 The environmental data for Landfill and Co-processing follows a previous study (Nagle et al., 2020) on LCA (Life Cycle Assessment) which used a functional unit of

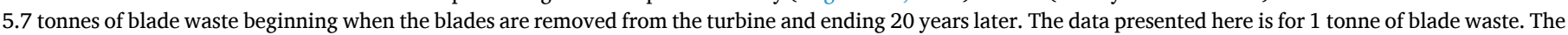

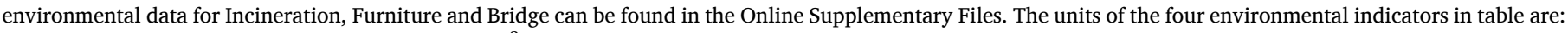
Eco-quality Potential Disability Fraction (PDF) per $\mathrm{m}^{2}$ and year; Disability Adjusted Life Years (DALY); MJ Primary Energy; and kg CO ${ }_{2}$ eq, respectively.

Table 2

Age Distribution of Wind Turbines in Ireland and Northern Ireland (Delaney et al., In Press).

\begin{tabular}{|c|c|c|c|}
\hline Decommissioning* & $\begin{array}{l}\text { Age } \\
\text { (yrs) }\end{array}$ & $\begin{array}{l}\text { Tonnes of } \\
\text { Blade } \\
\text { Waste }\end{array}$ & Remark \\
\hline $\begin{array}{l}\text { before } 2020 \\
2021-2025 \\
2026-2030 \\
2031-2035\end{array}$ & $\begin{array}{l}20+ \\
15-19 \\
10-14 \\
5-9\end{array}$ & $\begin{array}{l}600 \\
4200 \\
12,000 \\
14,000\end{array}$ & $\begin{array}{l}\text { The island of Ireland has over } \\
5000 \text { wind turbine blades with } \\
\text { the majority ( } 81 \% \text { ) ranging } \\
\text { between } 20 \text { m and } 45 \mathrm{~m} \text {, while } \\
\text { only a small number are being } \\
\text { decommissioned now (2021) } \\
\text { many more will follow. These are } \\
\text { distributed widely across the } \\
\text { whole island with most in the } \\
\text { northern or southern regions. } \\
\text { They are noticeably absent from } \\
\text { the highly populated areas } \\
\text { around Dublin and south of } \\
\text { Belfast, and they are sparse in the } \\
\text { central midlands. }\end{array}$ \\
\hline
\end{tabular}

*20 years is assumed as the life time of the blades.

metrics are in some sense universal, the economic metric values depend on a specific location. For this investigation Ireland is chosen as a location because it has a great deal of wind power installed already and within the next five years, around 4800 tonnes of blades will reach decommissioning stage (see Section 2.1.1).

\subsubsection{Ireland}

Ireland has the highest penetration of onshore wind in Europe (WindEurope, 2021) which provided 30\% of Ireland's electricity in 2018 (SEAI, 2021). Of particular importance for this investigation, is that the first wind turbines were installed in 1992 and so there is already a stream of decommissioned blades (see Table 2).

A Geographical Information System (ArcGIS Pro-Version 2.5) is used to calculate the average distances from the windfarms to the nearest suitable sites for the five end-of-life alternatives (Delaney et al., 2021). The mean distance to a landfill site which takes composite waste is 113 $\mathrm{km}$, to an incinerator is $214 \mathrm{~km}$ and to a cement kiln $131 \mathrm{~km}$. For the last two alternatives (furniture making and bridge fabrication), it is reasonable to assume that new factories may be built in small towns to take advantage of the supply of cheap raw material from nearby windfarms. A population threshold of 10,000 can be used by the same geographical information science (GIS) methodology to determine service centres and is comparable with 'market' towns which often experience adequate service provision (NISRA, 2015). Therefore, it is assumed for later calculations that the facilities for furniture making and bridge fabrication are on average $29 \mathrm{~km}$ from windfarms.

Ireland provides a case study for the relative merits of the five alternatives but the Irish data are not unique. For example, the LCA measures for climate change, pollution or health are not heavily dependant on location and will be similar across the globe. Even the local data for the salary and educational levels for various alternatives will be broadly similar in other European locations.

\subsubsection{Data description}

The values of the metrics in Table 1 are derived from both quantitative and qualitative sources. These include quantitative data from the Irish national census, real options analysis and life cycle assessment, and qualitative data from Delphi Studies, strength/weaknesses, opportunities/threats (SWOT) analysis and expert opinions. The evaluation processes are explained below followed by a short technical note on normalizing the data.

2.1.2.1. Economic input metrics. To determine scores for the economic input metrics in Table 1, several sources are used.

For the first economic input metric, Salary, the Irish Central Statistics Office (CSO, 2020a) provides representative salaries for the average worker in various types of jobs which are similar to the main employment offered by the five end-of-life alternatives. While the selection of jobs similar to those proposed in the five alternatives is important, the more important consideration is the amount of time taken per tonne of GFRP as this will vary considerably between alternatives, while the pay 
Table 3

Economic input metrics.

\begin{tabular}{|c|c|c|c|c|c|c|}
\hline \multicolumn{7}{|c|}{ a. Salary and hours of work per tonne GFRP } \\
\hline $\begin{array}{l}\text { Blade end-of-life } \\
\text { blade alternatives }\end{array}$ & $\begin{array}{l}\text { Transport modes, } \\
\text { Load (t), Speed } \\
(\mathrm{kmph})\end{array}$ & Round trip, km & $\begin{array}{l}\text { Hours of transport per } \\
\text { tonne }\end{array}$ & Hours of labour per tonne & $\begin{array}{l}\text { Total hours of work per } \\
\text { tonne }\end{array}$ & $\begin{array}{l}\text { Total salaries } \\
\text { per tonne, } €\end{array}$ \\
\hline Landfill & $\begin{array}{l}\text { Large truck, } 6 \mathrm{t} \text {, } \\
60 \mathrm{kmph}\end{array}$ & 296 & 0.82 & 0.50 & 1.32 & 31.83 \\
\hline $\begin{array}{l}\text { Incineration with } \\
\text { Heat Recovery }\end{array}$ & $\begin{array}{l}\text { Large truck, } 6 \mathrm{t} \text {, } \\
60 \mathrm{kmph}\end{array}$ & 457 & 1.27 & 0.58 & 1.85 & 44.40 \\
\hline $\begin{array}{l}\text { Co-Processing (in } \\
\text { Germany) }\end{array}$ & $\begin{array}{l}\text { Large truck, } 6 \mathrm{t} \text {, } \\
60 \mathrm{kmph}\end{array}$ & 729 & 2.03 & 1.63 & 3.66 & 88.62 \\
\hline $\begin{array}{l}\text { Furniture } \\
\text { Manufacturing }\end{array}$ & $\begin{array}{l}\text { Large truck, } 3 \mathrm{t} \text {, } \\
60 \mathrm{kmph}\end{array}$ & 59 & 0.25 & 19.00 & 19.25 & 486.24 \\
\hline Bridge Fabrication & $\begin{array}{l}\text { HGV trailer, 1t, } 30 \\
\text { kmph }\end{array}$ & 59 & 0.49 & 19.25 & 19.74 & 498.29 \\
\hline \multicolumn{7}{|c|}{ b. SWOT scores for commercial potential input metrics } \\
\hline & & Strengths (Score) & Weaknesses (Score) & Opportunities (Score) & Threats (Score) & $\begin{array}{l}\text { Score }(\mathrm{S}-W+ \\
O-\mathrm{T})\end{array}$ \\
\hline Landfill & & $\begin{array}{l}\text { Availability, } \\
\text { Scalability (3.7) }\end{array}$ & $\begin{array}{l}\text { Socially not popular and } \\
\text { may be become expensive } \\
(4.0)\end{array}$ & $\begin{array}{l}\text { Can cope with larger } \\
\text { quantities (2.7) }\end{array}$ & $\begin{array}{l}\text { Increasingly strict } \\
\text { regulation and fee } \\
\text { increases are likely (4.0) }\end{array}$ & -1.7 \\
\hline Incineration with $\mathrm{He}$ & Recovery & $\begin{array}{l}\text { Generates some } \\
\text { income, Availability } \\
(3.8)\end{array}$ & Liable to EUA prices (3.0) & $\begin{array}{l}\text { Can cope with large } \\
\text { quantities (4.0) }\end{array}$ & $\begin{array}{l}\text { Emissions legislation } \\
(4.2)\end{array}$ & 0.7 \\
\hline Co-Processing & & $\begin{array}{l}\text { Generates some } \\
\text { income, Recyclable } \\
\text { image (3.7) }\end{array}$ & Investment needed (2.3) & $\begin{array}{l}\text { Can cope with large } \\
\text { quantities (4.3) }\end{array}$ & $\begin{array}{l}\text { Emissions legislation } \\
\text { (3.5) }\end{array}$ & 2.2 \\
\hline Furniture Manufactur & & $\begin{array}{l}\text { Very profitable, Large } \\
\text { market, Green image } \\
(4.3)\end{array}$ & $\begin{array}{l}\text { Curved blades are } \\
\text { awkward to work with } \\
(2.7)\end{array}$ & $\begin{array}{l}\text { Green image, large market } \\
\text { for repurposed goods ( } 4.0 \text { ) }\end{array}$ & $\begin{array}{l}\text { Raw material consistency } \\
\text { (1.7) }\end{array}$ & 4.3 \\
\hline Bridge Fabrication & & $\begin{array}{l}\text { Profitable, Green } \\
\text { image (4.3) }\end{array}$ & $\begin{array}{l}\text { Small market, Civil } \\
\text { engineering approval may } \\
\text { be difficult, }(3.8)\end{array}$ & $\begin{array}{l}\text { Green image, cheap material, } \\
\text { Technology can expand to } \\
\text { other uses ( } 4.0)\end{array}$ & $\begin{array}{l}\text { Unforeseen properties of } \\
\text { composites, Certification } \\
(2.8)\end{array}$ & 1.7 \\
\hline \multicolumn{7}{|c|}{ c. Real option model parameters for determining the R\&D values, based on (Deeney et al., 2021) } \\
\hline & & Landfill & $\begin{array}{l}\text { Incineration with Heat } \\
\text { Recovery }\end{array}$ & Co-Processing & Furniture Making & $\begin{array}{l}\text { Bridge } \\
\text { Fabrication }\end{array}$ \\
\hline \multicolumn{2}{|c|}{ R\&D implementation, $€$} & 100,000 & 500,000 & 500,000 & $5,000,000$ & $5,000,000$ \\
\hline \multicolumn{2}{|l|}{ Fixed Monthly Cost, $€$} & 500 & 1000 & 1000 & 50,000 & 50,000 \\
\hline \multicolumn{2}{|c|}{ Fixed cost monthly growth rate } & 0.01 & 0.01 & 0.01 & 0.01 & 0.01 \\
\hline \multicolumn{2}{|c|}{ Implementation time, months } & 12 & 12 & 12 & 12 & 12 \\
\hline \multicolumn{2}{|c|}{ Implementation duration, months } & 240 & 240 & 240 & 240 & 240 \\
\hline \multicolumn{2}{|c|}{ GFRP Amount, t/month } & 267 & 267 & 267 & 267 & 60 \\
\hline \multicolumn{2}{|c|}{ Initial income, $€ / \mathrm{t}$} & 38 & 200 & 200 & 4051 & 6000 \\
\hline \multicolumn{2}{|l|}{ Labour cost, $€ / \mathrm{t}$} & 29 & 37 & 60 & 1027 & 1035 \\
\hline \multicolumn{2}{|l|}{ Liable to EU ETS } & 0 & 1 & 1 & 0 & 0 \\
\hline \multicolumn{2}{|c|}{ Initial running cost, $€ / \mathrm{t}$ ) } & 10 & 20 & 25 & 500 & 1000 \\
\hline \multicolumn{2}{|l|}{ Cost change factor } & 0.8 & 0.8 & 0.7 & 0.5 & 0.25 \\
\hline \multicolumn{2}{|l|}{ Carbon capture $€ / \mathrm{t}$} & 40 & 40 & 40 & 40 & 40 \\
\hline \multicolumn{2}{|c|}{ European Emission Allowances price, $€ / \mathrm{t}$} & 30 & 30 & 30 & 30 & 30 \\
\hline \multicolumn{2}{|l|}{ Final value $€ \mathrm{~m}$} & 6.8 & 15.6 & 13.0 & 232.9 & 73.8 \\
\hline
\end{tabular}

rates per hour are quite similar. As mentioned in Section 2.1.1, the estimate of transport hours uses information from GIS for the mean distance from windfarms to the nearest market town, the nearest landfill and the nearest incinerator. It is assumed here that co-processing takes place in Germany and therefore involves considerable transport time (see Table 3, panel a). Using the GIS data, a subgroup of authors with specific expertise in business, sociology and geography estimated the times required for transport and labour, and hence the Salary metric.

In order to estimate the Commercial Potential (potential of the alternatives becoming a profitable business) of the five alternatives, four academics with expertise in circular business models and energy finance are surveyed. A SWOT analysis (Helms and Nixon, 2010; Tugrul and Cimen, 2016; Coelho Junior et al., 2020) is used to compare the Commercial Potential of the five alternatives. The score for each alternative is given by: Score $=S-W+O-\mathrm{T}$, where $\mathrm{S}, \mathrm{W}, \mathrm{O}$ and $\mathrm{T}$ are the marks out of five for strengths, weaknesses, opportunities and threats averaged over the participants. The rationale for the decisions is further explained in Online Supplementary Files, and the scores from the exercise are given in Table 3 (panel b).

As an indication of the future opportunities of the alternatives the $\boldsymbol{R} \& \boldsymbol{D}$ Value may be estimated by real options analysis methods which are used extensively to evaluate R\&D investments (Herath and Park, 2002; Cassimon et al., 2011; Fernandes et al., 2011; Wesseh and Lin, 2015). The method of (Deeney et al., 2021) is used, which considers the value of an $R \& D$ process which is developed to reduce the cost of each alternative while considering the random natures of the income and expenditure of each alternative in a carbon trading environment. The values of the parameters used for the R\&D pricing model for each of the five alternatives are shown in used for the $R \& D$ pricing model for each of the five alternatives are shown in Table 3 (panel c) which summarises the salary and hours of work calculations. The hours of work and transport which are required for the total salaries is estimated by the group who provided the SWOT analysis. An estimate of the income from furniture is based on IKEA prices. The overall parameters of R\&D model are taken from Deeney et al. (2021) and kept the same for each alternative to allow a fair comparison. Carbon capture price is based on IEA, 2019,(IEA, 2019a).

(More details can be found in the Online Supplementary Files.

2.1.2.2. Social input metrics. Hours of Work, which measures the time needed to process a tonne of GFRP for each alternative, is used as a source for scoring the first social input metric in Table 1. This gives a 
measure of the employment which can be expected per tonne of blade waste. The estimates are based on discussions with the same group of academic experts as supplied the SWOT analysis.

The Educational Level data is taken from the 2016 Irish Census data (CSO, 2020b) for maximum educational attainment for a selection of jobs. The scale changes from 1 for a basic primary level education to 10 for a doctoral degree and are weighted according to the numbers of people in the particular type of job (see Online Supplementary Files for details).

In order to assess the level of Community Support (i.e., community approval and lack of objection) for the five alternatives, a Delphi/AHP study with two rounds (as explained in Section 2.2) was conducted amongst an expert group of ten sociologists and academics with experience in community work in an Irish context, following (Revez et al., 2020). They were questioned about what in their opinion, would be the level of community support for the various alternatives.

For the Accident Rate input metric, the Irish Health and Safety Authority (HSA, 2018) was a source of data on the rates of fatalities by economic sectors. HSA figures show that, in general, the fatality rates of workers in Transport and Storage sector are twice that in the Industry sector. Those rates are 4 and 2 per 100,000 workers of the sectors, respectively.

2.1.2.3. Environmental input metrics. The environmental metrics, Ecosystem Quality, Human Health, Resources and GHG are taken from life cycle assessment (LCA). The functional unit is the disposition of one tonne of decommissioned wind turbine blade material for 20 years. The assumptions are that co-processing happens in Germany, that bridges are disposed of using co-processing and furniture is disposed of by landfill. LCA software SimaPro 9.0.0.3 (PRe Sustainability, 2019) is used, in conjunction with life cycle inventory database EcoInvent 3.6 (Wernet et al., 2016). Within SimaPro, life cycle impact assessment method IMPACT2002+ (Humbert et al., 2015) is used, which reports impacts in both midpoint and endpoint categories, and incorporates the IPCC 100-year time frame for Climate Change impacts. Ecosystem Quality units are expressed in 'Potentially Disappeared Fraction of species over $1 \mathrm{~m}^{2}$ over 1 year' (PDF* $\mathrm{m}^{2 * \mathrm{yr}}$ ). Human Health is expressed in disability adjusted life years (DALYs). Resources is expressed in mega joules (MJ) and combines non-renewable energy consumption and mineral extraction. $G H G$ is the sum of all greenhouse gasses expressed in $\mathrm{kg}$ of carbon dioxide equivalents.

\subsubsection{Normalization}

All the metrics are normalised onto a scale from zero to one, where zero is the least beneficial/desirable and one is the most beneficial/ desirable following (Clark et al., 2020) and (Horan, 2020). The following transformations, in Eq. (1) and Eq. (2), are proposed from the metric's original value (x), to the normalised value (y). For "beneficial" metrics where a larger value of the metric is more beneficial (Salary, Commercial Potential, R\&D Value, Hours of Work, Education Level and Community Support) Eq. (1) is used.

$y=\frac{x-\min \{X\}}{\max \{X\}-\min \{X\}}$

where, $X$ is the set of $x$ values taken by the five alternatives. Applying this to the first economic metric, Salary, and taking the following values from Table $1 \mathrm{a}, X=\{31.83,44.40,88.62,486.24,498.29\}$ with a $\min \{\mathrm{X}\}$ $=31.83$ and $\max \{X\}=498.29$ we have $Y=\{0,0.03,0.12,0.97,1\}$.

The "non-beneficial" metrics are: Accident Rate, Ecosystem Quality, Human Health, Resources and GHG. For these metrics, a greater number is less desirable than a smaller number. For these metrics, (2) is used.

$y=\frac{\max \{X\}-x}{\max \{X\}-\min \{X\}}$

\subsection{Delphi study/AHP analysis to establish weighting factors}

In order to combine the metrics into the Sustainability Indices using the MCDA methods, it is necessary to have weighting factors for the three dimensions of sustainability, economic, social and environmental, and to have weighting factors for the metrics. To obtain these a Delphi Study is carried out amongst 20 members of an international research network, $R e$-Wind ${ }^{2}$ based in Ireland, UK and USA, were contacted for the Delphi Study/AHP Analysis. These researchers have spent several years examining composite recycling and end-of-life alternatives for wind blades including manufacturing of housing, bridges, pylons, shore groynes and traffic noise barriers (Bank, Arias, et al., 2018; Bank, Chen, et al., 2018; Yazdanbakhsh et al., 2018). The use of academic experts in a Delphi study follows (Herath and Park, 2002; Park et al., 2020; Revez et al., 2020). Fifteen participants responded to the first round and 13 of these responded to the second round. The use of 13 respondents with two Delphi rounds, is within the normal range for Delphi Studies (Diamond et al., 2014; Van Schoubroeck et al., 2019).

In the first round of the Delphi Study each respondent completed four sets of pairwise comparisons (red rectangles in Fig. 1) which were used to build AHP pairwise comparison matrices (PCMs) following (Saaty, 2002). Respondents also provided short statements of their reasoning.

The first set of pairwise comparisons related to the relative importance of the Economic metrics of Salary, Commercial Potential and R\&D Value; the second related to the relative importance of the Social metrics of Hours of Work, Education Level, Community Support and Accident Rate; the third related to the relative importance of the Environmental metrics of Ecosystem Quality, Human Health, Resources and greenhouse gases $(G H G)$ and the fourth related to relative importance of Economic, Social and Environmental sustainability.

In the second round the participants were given the weights as calculated by AHP from the first round, and an anonymised list of the statements explaining the rationale for the decisions. They were asked to repeat the pairwise comparisons. After the second round the Delphi Study concluded as the three stopping conditions of consensus, consistency and convergence were met (Section 2.2.1) were met.

\subsubsection{Consensus, consistency and convergence conditions}

It is important to have an objective and practical method to decide when to conclude a Delphi Study (Diamond et al., 2014). The following stopping conditions requiring consensus, consistency and convergence were used.

Consensus can be tested with the Kendall's W statistic (Kendall and Smith, 1939; Yusof et al., 2018) which ranges from a value of 0 for no consensus to a value of 1 for unanimity. The method to calculate Kendall's $\mathrm{W}$ uses the ranking order given by each participant. It is therefore invariant to the specific strength of opinion expressed by the participants, thus each participant has the same influence on the degree of consensus. To develop a consensus stopping condition, let $K_{i}$ be the value of Kendall's W from the $i^{\text {th }}$ round of a Delphi study. Then the possible improvement after the next Delphi round can range from $\mathrm{K}_{\mathrm{i}}$ to 1 ; it would be impossible for a high value of $K_{i}$, such as 0.8 , to increase by more than 0.2 from the $\mathrm{i}^{\text {th }}$ round to the next round (the $i+1$ th round). It is therefore suggested that a stopping condition be an improvement of at least $5 \%$ of the maximum possible improvement, i.e. if $\left(\mathrm{K}_{\mathrm{i}+1}-\mathrm{K}_{\mathrm{i}}\right) /\left(1-\mathrm{K}_{\mathrm{i}}\right)>0.05$, then the Delphi study may stop (if the other two stopping conditions below are also fulfilled).

The next stopping condition is consistency. The PCM records a series of paired comparisons not a multiple simultaneous comparison. For example given three choices, $\mathrm{A}, \mathrm{B}$ and $\mathrm{C}$ it is at least theoretically possible for a respondent to prefer choice A to B, B to C and C to A, which is inconsistent. (Ergu and Kou, 2012) and (Lin et al., 2013) find that it is hard to get perfect consistency for several reasons: humans do not

\footnotetext{
${ }^{2}$ Website available at www.re-wind.info
} 
usually think entirely logically; the decisions being made by the respondents are complex; and the scale used for their responses may also present difficulties. It is therefore important to use a testing condition for consistency.

The most widely used AHP consistency test from (Saaty, 2002) compares the consistency index, CI, of the PCM with the mean consistency index, CR, of randomly generated similar sized matrices. The consistency index is defined as, $C I=\frac{\lambda-n}{n-1}$ where $\lambda$ is the maximum eigenvalue of the PCM and $\mathrm{n}$ is the order of the square PCM (the number being compared). If the PCM is perfectly consistent then $\mathrm{CI}$ is zero. AHP consistency test is that the ratio of CI/CR is less than a given threshold. The given thresholds are $0.05,0.08$ and 0.10 for PCMs of size three, four and five or more.

Finally, to be assured that the experts are gradually converging to an agreed opinion rather than oscillating between divergent positions, a convergence condition is imposed. The weights are the normalized eigenvectors corresponding to the largest eigenvalue of the PCM matrices (Saaty, 2002). Let the weight distance $d_{i}$, between two sets of weights of length $n$ from consecutive rounds producing the weights $\left(w_{i, 1}\right.$, $\left.w_{i, 2}, \ldots, w_{i, n}\right)$ and $\left(w_{i+1,1}, w_{i+1,2}, \ldots, w_{i+1, n}\right)$ from the $\mathrm{i}^{\text {th }}$ and subsequent $(i$ +1 th) Delphi rounds is defined by Eq. (3) The convergence condition is that $\mathrm{d}_{\mathrm{i}}<0.05$.

$d_{i}=\frac{1}{n} \sum_{k=1}^{n}\left(w_{i, k}-w_{i+1, k}\right)^{2}$

When all three conditions for consensus, consistency and convergence are met the Delphi process may conclude because the weights agree with each other (consensus), are logically consistent and are stable (convergent).

\subsection{Construction of sustainability indices and integrated indices using $M C D A$}

With the weights obtained from the Delphi Study (Section 2.2), Economic, Social and Environmental Sustainability Indices are created using each of the MCDA methods: AHP, PROMETHEE and ELECTRE (three green circles in Fig. 1). These three MCDA methods are now described, followed by a description of the method to produce integrated sustainability indices.

\subsubsection{Economic, social and environmental sustainability indices}

AHP supplies three services to this investigation: (i) it provides a theoretical framework for the arrangement of the SDGs into a hierarchy under the three dimensions of Economy, Society and Environment; (ii) it allows the qualitative information from the Delphi Study to be synthesised into quantitative data; and (iii) the AHP consistency measure is used as one of the stopping conditions for the Delphi Study as explained in the previous section. The last use of AHP is, to the best of the authors' knowledge, a contribution to the literature.

Explicitly, the AHP Sustainability Indices (SI) are defined as follows in (4), Eqs. (4)-(6), where $j=1,2, . ., 5$ indicates the five alternatives.:

$$
\begin{aligned}
& \operatorname{EconomicSI}_{A H P}(j)=N(\operatorname{Sal}(j)) \cdot w_{\text {Sal }}+N(\operatorname{ComPot}(j)) \cdot w_{\text {ComPot }} \\
& +N(R \& D(j)) \cdot w_{R \& D} \\
& \operatorname{SocialSI}_{A H P}(j)=N(\operatorname{Hours}(j)) \cdot w_{\text {Hours }}+N(E d u(j)) \cdot w_{E d u} \\
& +N(\operatorname{ComSup}(j)) \cdot w_{\text {ComSup }}+N(\operatorname{Acc}(j)) \cdot w_{\text {Acc }} \\
& \text { EnvironmentalSI }_{A H P}(j)=N(\operatorname{Eco}(j)) \cdot w_{E c o}+N(H u m(j)) \cdot w_{H u m} \\
& +N(\operatorname{Res}(j)) \cdot w_{\text {Res }}+N(G H G(j)) \cdot w_{G H G}
\end{aligned}
$$

Where, each $w_{k}$ indicates the weight of the $k$ metric, so that for example: $w_{\text {Sal }}+w_{\text {ComPot }}+w_{R \& D}=1$, etc. and $\mathrm{N}$ indicates the normalisation function as described in Section 2.1.3, $\operatorname{Sal}(j)$ is the value of the Salary input metric for alternative $j$, etc.
This produces three sustainability indices using AHP, which allocate a score to each of the five alternatives, the larger the number the greater the level of sustainability.

PROMETHEE is reasonably easy to use, it works well for real life problems and gives a complete scored ranking of the alternatives (Pohekar and Ramachandran, 2004; Vavatsikos et al., 2020). It is therefore a useful way to confirm the AHP results. PROMETHEE is used to provide a complete ranking of the alternatives following (Brans and Vincke, 1985). It takes the input metrics and their weights to produce a sustainability index for each dimension. The resulting indices are quite similar to the sustainability indices using AHP, in that both produce numerical scores. For technical details see (Brans et al., 1984; Brans and Vincke, 1985).

ELECTRE is different from AHP or PROMETHEE, in that it produces a ranking of the alternatives rather than numerical scores. Specifically, it provides a matrix which indicates the relative pairwise rankings (Zanakis et al., 1998) of the five alternatives. ELECTRE uses the input metrics and their weights to produce the three Sustainability Indices. ELECTRE has been used extensively for environmental and business management (Govindan and Jepsen, 2016). Sometimes ELECTRE does not produce a clear overall ranking of all of the alternatives, however it is very useful as it offers a different perspective from AHP and PROMETHEE. For details see (Almeida, 2007).

\subsubsection{Integrated sustainability indices}

The integrated sustainability indices combine the three sustainability indices so that it might be clear which of the five alternatives are the most sustainable. The construction of the AHP, PROMETHEE and ELECTRE integrated Sustainability Indices follows.

AHP is used to combine the three Sustainability Indices into a single AHP Integrated Sustainability Index in Eq. (7) by multiplying the index values for alternative $\mathrm{j}$, by the weights for the individual indices, thus,

$$
\begin{aligned}
\text { IntegratedSI }_{A H P}(j)= & \text { Economic } S_{A H P}(j) \cdot w_{E c o n}+\operatorname{Social~SI}_{A H P}(j) \cdot w_{S o c} \\
& + \text { Environmental } S_{A H P}(j) \cdot w_{E n v}
\end{aligned}
$$

where the weights $\left(w_{E c o n}, w_{S o c}, w_{E n v}\right)$ are determined by the Delphi Study and the three Sustainability Indices are defined in (4), Eq. (4), Eq. (5) and Eq. (6). The three weights expresses the relative importance of the economic, social and environmental dimensions of sustainability.

The AHP Integrated Sustainability Index may also be expressed in (9) when the concept of a generalized weight is introduced. The generalized weight is the weight of an individual metric which takes into account the weight of its dimension, thus for example the generalized weight of salary $\left(G W_{s a l}\right)$ is obtained by multiplying the Economic weight $\left(W_{E c o n}\right)$ by the salary weight $\left(W_{S a l}\right)$, where the economic weight is chosen because Salary is an economic metric. These generalised weights are given by Eq. 8:

$$
\begin{gathered}
G w_{\text {Sal }}=w_{E c o n} \cdot w_{\text {Sal }}, G w_{C o m P o t}=w_{E c o n} \cdot w_{C o m P o t}, G w_{R \& D}=w_{E c o n} \cdot w_{R \& D} ; \\
G w_{H o u r s}=w_{S o c} \cdot w_{H o u r s}, G w_{E d u}=w_{S o c} \cdot w_{E d u}, G w_{C o m S u p}=w_{S o c} \cdot w_{C o m S u p}, G w_{A c c}=w_{S o c} \cdot w_{A c c} ; \\
G w_{E c o}=w_{E n v} \cdot w_{E c o}, G w_{H u m}=w_{E n v} \cdot w_{H u m}, G w_{R e s}=w_{E n v} \cdot w_{R e s}, G w_{G H G}=w_{E n v} \cdot w_{G H G} .
\end{gathered}
$$

Therefore

IntegratedSI $_{A H P}(j)=\sum_{i=1}^{11} G w_{i} N\left(m_{j}\right)$

where $i=1, . ., 11$ represents all eleven metrics which have a value of $\mathrm{m}_{\mathrm{j}}$ for alternative $\mathrm{j}$, which is normalized as $\mathrm{N}\left(\mathrm{m}_{\mathrm{j}}\right)$. Since Eq. (9) has the same format as (4), Eq. (4), Eq. (5) and Eq. (6) it is seen that these generalized weights make it possible to directly compare the relative importance of all of the metrics, even those from different dimensions of sustainability. This offers an interesting perspective on the diverse metrics, at least from an integrated AHP point of view.

The integrated SI using PROMETHEE is produced by using the three 


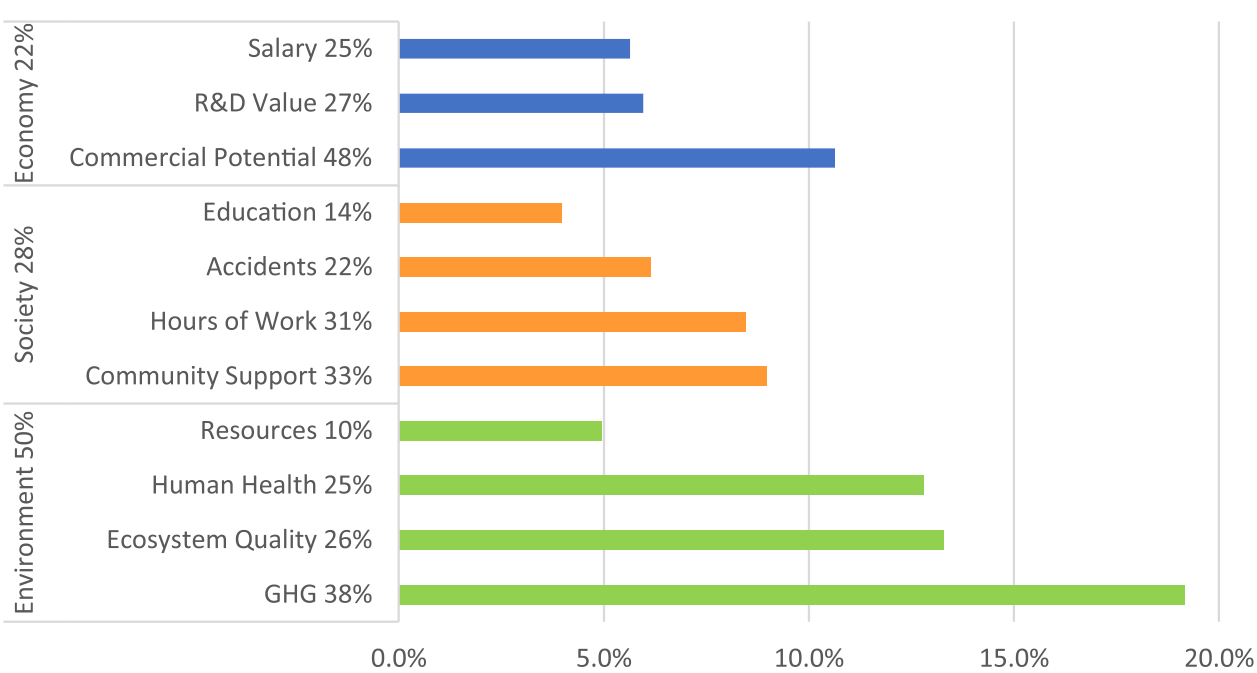

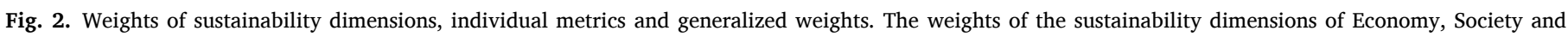

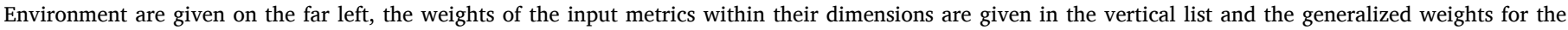
dimensions are indicated in the bar chart.

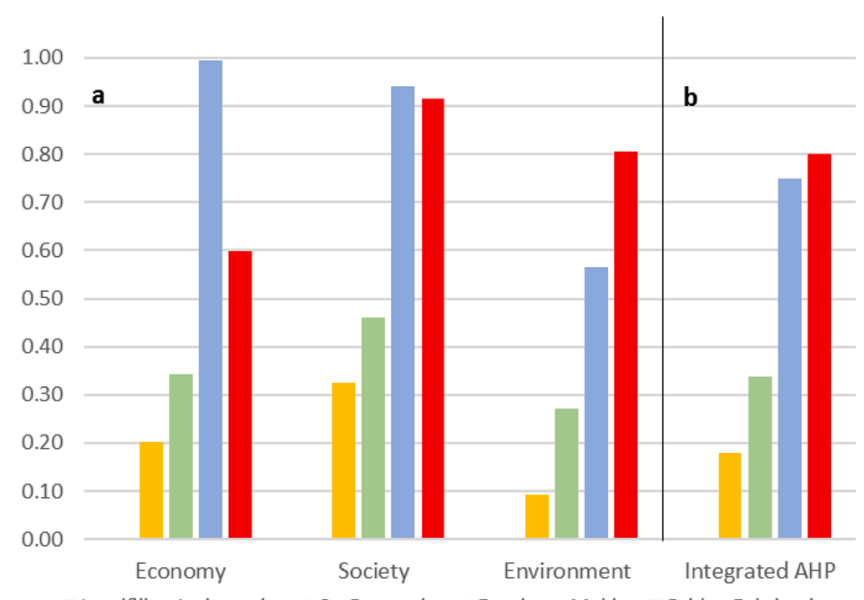

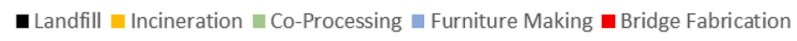

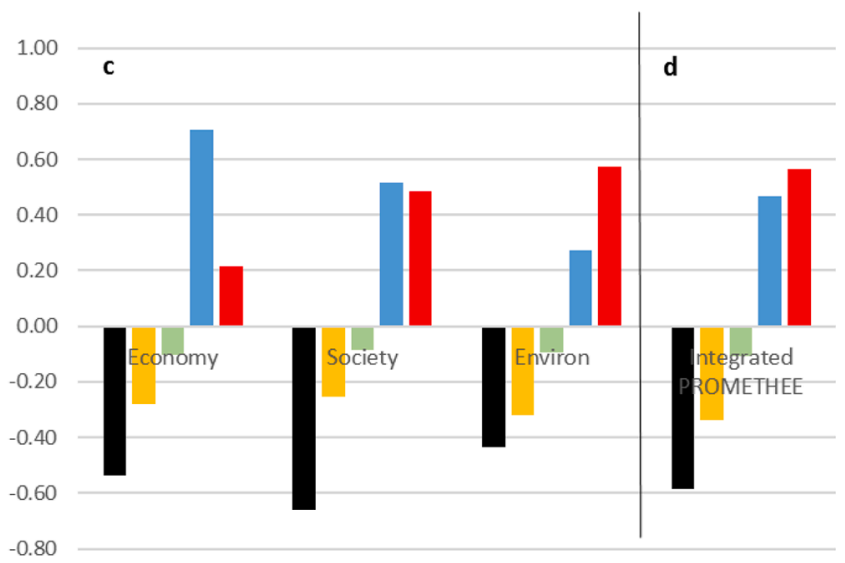

- Landfill $=$ Incineration $\mathbf{m}$ Co-Processing $\mathbf{a}$ Furniture Making $\mathbf{a}$ Bridge Fabrication

Fig. 3. AHP and PROMETHEE Sustainability Indices. Panels a and c show the AHP and PROMETHEE Sustainability Indices for the three dimensions of Economy, Society and Environment. Panel b and d show the Integrated indices for AHP and PROMETHEE. Note that Landfill scores zero on all the indices in AHP.
PROMETHEE Sustainability Index values for each alternative and the weights for each dimension $\left(w_{E c o n}, w_{S o c}, w_{E n v}\right)$, as the inputs for a second application of PROMETHEE. Note that applying PROMETHEE once to all eleven metrics using the generalized weights does not produce the same result.

ELECTRE does not produce values but it produces ranking positions. These numbers, even if they make a complete set of rankings, are not usable by ELECTRE for a second application to calculate an integrated Sustainability Index. To make an ELECTRE integrated sustainability index it is therefore necessary to use the Generalised weights and to apply ELECTRE to all eleven metrics at once.

\section{Results and discussion}

\subsection{Sustainability dimension of the individual dsdg metrics}

The Delphi Study in Section 2.2 produced the weights for the individual metrics within their dimensions and the weights for the dimensions (economic, social and environmental) as displayed in Fig. 2. Within the economic metrics it is noticeable that the weight for Commercial Potential is roughly twice that of the other two. This may indicate that the future expectation of success, as measured by this metric, is a

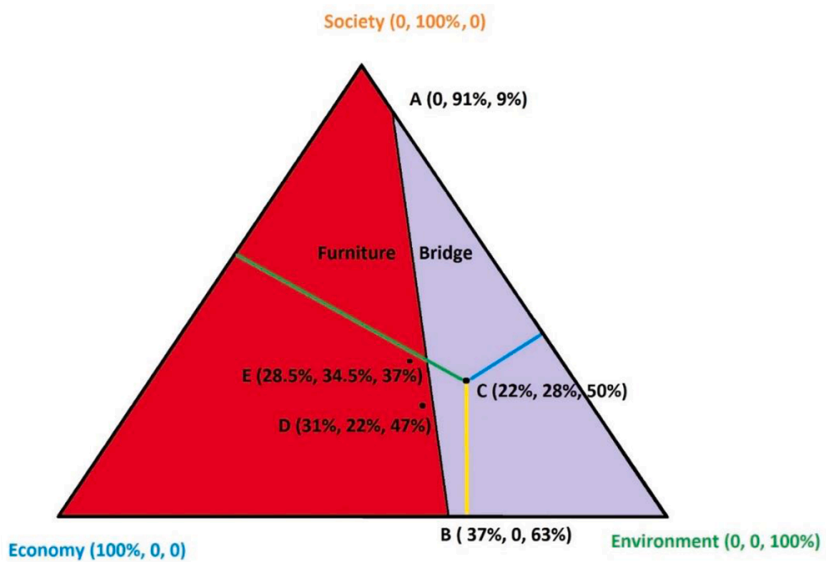

Fig. 4. Ternary Plot of Dimension Weights showing areas where furniture making is in first place (red) and where bridge fabrication is in first place (purple). A, B, C, D, E are explained in text. 
more pertinent indicator of economic sustainability than the current salaries or the possibility of future R\&D improvements. Within the Social metrics it is seen that Community Support and Hours of Work carry the most of the weight. This may be a result of the importance of community agreement for wind farm developments and the need for community benefits from renewable energy projects (Rogers et al., 2008; Cowell et al., 2011). It may also indicate that worker welfare (as measured by Education and Accidents) is now taken for granted. Within the environmental metrics it is clear that GHG output is considered by far the most important consideration of environmental sustainability. One of the participants gave the following as part of their rationale, "Greenhouse Gas reduction is time critical at the moment - it should be prioritised over any other indicator".

Between the three dimensions the weight given to the environment is roughly twice that of the other two dimensions. This may be a result of the people whose opinions were sought, they were a group of researchers. In the sensitivity analysis (see Section 3.3) this possible source of bias will be explored. One participant gave the following rationale: "I think that social criteria is important as it will encourage people to engage with reuse. However, I think environmental is most important as it relates to accountability of choices. I recognize that economic is important, but I do not value it in relation to the others."

To compare metrics from different dimensions, generalized weights were introduced (8) which take account of both the weight of the metric within the dimension, and the weight of the dimension. Generalized weights are displayed in the horizontal bars of Fig. 2, which make it clear that $G H G$ is much more important than any of the other metrics, which is not immediately apparent from the weight of $38 \%$ for $G H G$ within the Environmental metrics and $48 \%$ to Commercial Potential within the Economic metrics. The weights within dimensions are listed for the eleven metrics and the generalized weights between the dimensions are listed on the left of Fig. 2.

Table 4

Sensitivity of Weights and Values of Metrics. In panel A Pink cells indicate that the first and second alternatives (bridge fabrication and furniture making) have swapped as a result of sensitivity. Yellow cells indicate no change. In panel B Pink cells indicate the swapping of (1st, 2nd,and 3rd,4th) places. D and E are explained in Ternary plot (Section 3.4).

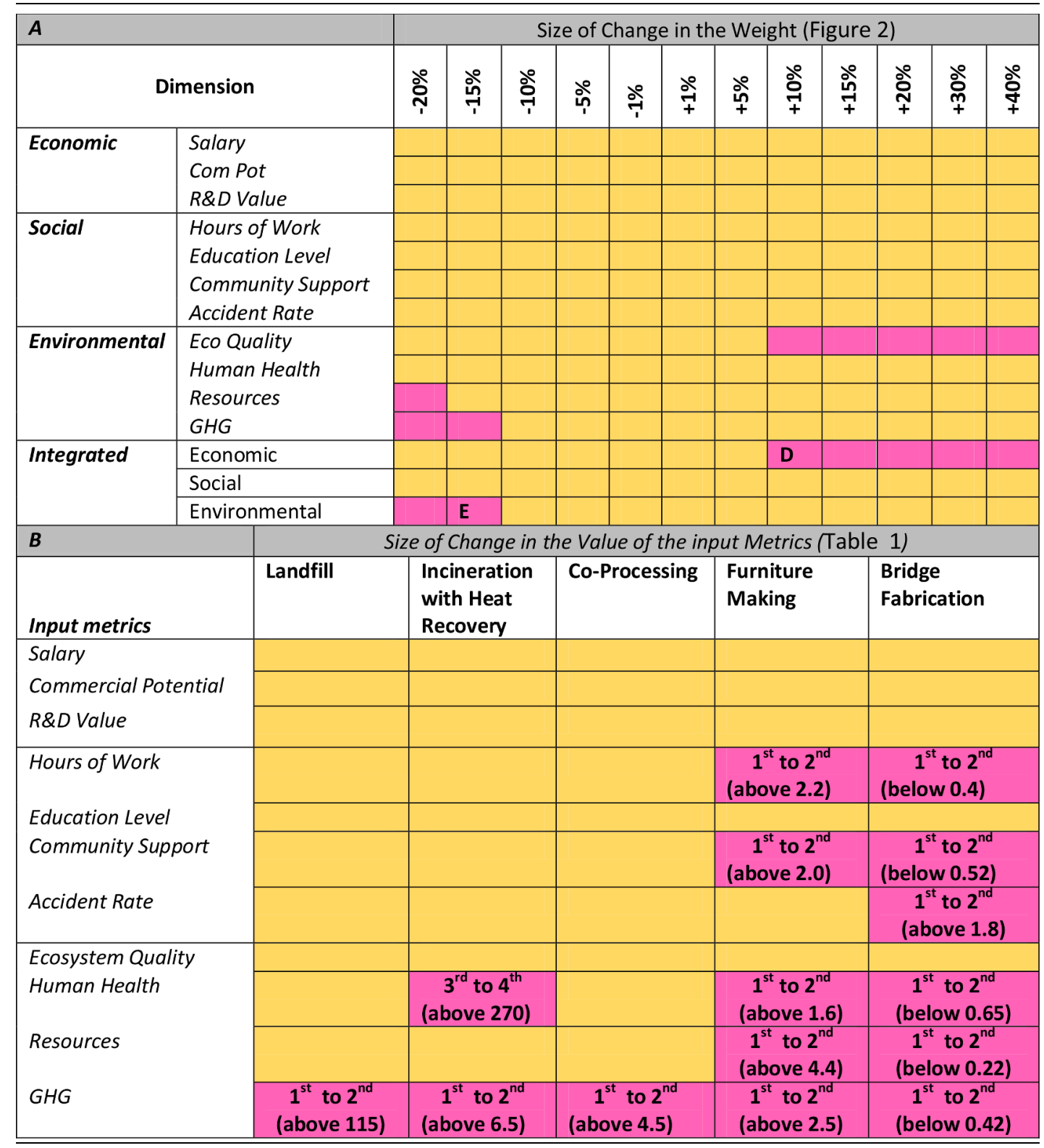




\begin{tabular}{|c|c|c|c|c|c|c|c|c|c|c|c|c|c|c|}
\hline \multicolumn{3}{|l|}{$A$} & \multicolumn{12}{|c|}{ Size of Change in the Weight (Figure 2) } \\
\hline \multicolumn{3}{|c|}{ Dimension } & ठ્సે & ओे & ठें & ڤั่ & ذे & 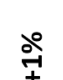 & 華 & ذ্ণ & ओั้ & จें & ठั & ذి \\
\hline \multirow[t]{3}{*}{ Economic } & \multirow{3}{*}{\multicolumn{2}{|c|}{$\begin{array}{l}\text { Salary } \\
\text { Com Pot } \\
R \& D \text { Value }\end{array}$}} & & & & & & & & & & & & \\
\hline & & & & & & & & & & & & & & \\
\hline & & & & & & & & & & & & & & \\
\hline \multirow[t]{4}{*}{ Social } & \multirow{4}{*}{\multicolumn{2}{|c|}{$\begin{array}{l}\text { Hours of Work } \\
\text { Education Level } \\
\text { Community Support } \\
\text { Accident Rate }\end{array}$}} & & & & & & & & & & & & \\
\hline & & & & & & & & & & & & & & \\
\hline & & & & & & & & & & & & & & \\
\hline & & & & & & & & & & & & & & \\
\hline \multirow[t]{4}{*}{ Environmental } & \multirow{4}{*}{\multicolumn{2}{|c|}{$\begin{array}{l}\text { Eco Quality } \\
\text { Human Health } \\
\text { Resources } \\
\text { GHG }\end{array}$}} & & & & & & & & & & & & \\
\hline & & & & & & & & & & & & & & \\
\hline & & & & & & & & & & & & & & \\
\hline & & & & & & & & & & & & & & \\
\hline \multirow[t]{3}{*}{ Integrated } & \multicolumn{2}{|c|}{ Economic } & & & & & & & & D & & & & \\
\hline & \multicolumn{2}{|c|}{ Social } & & & & & & & & & & & & \\
\hline & \multicolumn{2}{|c|}{ Environmental } & & E & & & & & & & & & & \\
\hline \multicolumn{3}{|l|}{$B$} & \multicolumn{12}{|c|}{ ize of Change in the Value of the input Metrics (Table 1) } \\
\hline \multicolumn{2}{|l|}{ Input metrics } & Landfill & \multicolumn{3}{|c|}{$\begin{array}{l}\text { Incineration } \\
\text { with Heat } \\
\text { Recovery } \\
\end{array}$} & \multicolumn{3}{|c|}{ Co-Processing } & \multicolumn{3}{|c|}{$\begin{array}{l}\text { Furniture } \\
\text { Making }\end{array}$} & \multicolumn{3}{|c|}{\begin{tabular}{|l|} 
Bridge \\
Fabrication
\end{tabular}} \\
\hline \multirow{3}{*}{\multicolumn{2}{|c|}{$\begin{array}{l}\text { Salary } \\
\text { Commercial Potential } \\
R \& D \text { Value }\end{array}$}} & & & & & & & & & & & & & \\
\hline & & & & & & & & & & & & & & \\
\hline & & & & & & & & & & & & & & \\
\hline \multirow{4}{*}{\multicolumn{2}{|c|}{$\begin{array}{l}\text { Hours of Work } \\
\text { Education Level } \\
\text { Community Support }\end{array}$}} & & & & & & & & $\begin{array}{r}1^{5} \\
\text { (abo }\end{array}$ & $\begin{array}{l}\text { to } 2^{n} \\
\text { ve } 2.2\end{array}$ & & $\begin{array}{r}1 \\
\text { (belo }\end{array}$ & $\begin{array}{l}\text { to } 2^{n} \\
w 0.4)\end{array}$ & \\
\hline & & & & & & & & & & & & & & \\
\hline & & & & & & & & & $\begin{array}{r}1 \\
\text { (abo }\end{array}$ & to $2^{n}$ & & $\begin{array}{r}1 \\
\text { (belo }\end{array}$ & $\begin{array}{l}\text { to } 2^{\text {n }} \\
\text { w } 0.52\end{array}$ & \\
\hline & & & & & & & & & & & & & $\begin{array}{l}\text { to } 2^{n} \\
\text { ove } 1 \text {. }\end{array}$ & \\
\hline \multirow{3}{*}{\multicolumn{2}{|c|}{$\begin{array}{l}\text { Ecosystem Quality } \\
\text { Human Health }\end{array}$}} & & & & & & & & & & & & & \\
\hline & & & & $\begin{array}{l}3^{\text {rd }} \text { to } \\
\text { oove } 2\end{array}$ & & & & & & 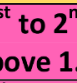 & & & $\begin{array}{l}\text { to } 2^{n} \\
\text { ow } 0 .\end{array}$ & \\
\hline & & & & & & & & & & to $2^{\prime}$ & & & $\begin{array}{l}\text { to } 2^{n} \\
\text { ow } 0 .\end{array}$ & \\
\hline \multicolumn{2}{|l|}{$G H G$} & $\begin{array}{l}1^{\text {st }} \text { to } 2^{\text {nd }} \\
\text { (above 115) }\end{array}$ & \multicolumn{3}{|c|}{$\begin{array}{l}1^{\text {st }} \text { to } 2^{\text {nd }} \\
\text { (above } 6.5 \text { ) }\end{array}$} & \multicolumn{3}{|c|}{$\begin{array}{l}1^{\text {st }} \text { to } 2^{\text {nd }} \\
\text { (above } 4.5 \text { ) }\end{array}$} & \multicolumn{3}{|c|}{$\begin{array}{l}1^{\text {st }} \text { to } 2^{\text {nd }} \\
\text { (above } 2.5 \text { ) }\end{array}$} & $\begin{array}{r}1 \\
\text { (be }\end{array}$ & $\begin{array}{l}\text { to } 2 \\
\text { ow } 0 .\end{array}$ & 42) \\
\hline
\end{tabular}

\subsection{Sustainability indices of alternatives}

Using the input metric values from Section 2.1, the weights from Section 2.2 and following the MCDA methods from Section 2.3, the three sustainability indices for each of the five alternatives as well as a single integrated sustainability index for the wind blade end-of-life alternatives are calculated and displayed in Fig. 2:

Fig. 3. The index scores from AHP (Fig. 3, a and b) for each alternative range from zero to 1 , where a larger score indicates a more sustainable alternative. The index scores for PROMETHEE (Fig. 3, c and d) can be positive or negative, with the more positive/less negative number indicating a more sustainable outcome.

Across all the indices it is seen that bridge fabrication and furniture making take first and second places as the most sustainable alternatives, with co-processing, incineration and landfill taking the remaining places in that order. Furniture making takes first place from the economic and social points of view, while bridge fabrication takes first place from an environmental point of view. Since there is a greater weight given to the environmental dimension, it is bridge fabrication which is seen to be the most sustainable alternative using the integrated sustainability indices.
Panels $a$ and $c$ in Fig. 3 show the AHP and PROMETHEE Sustainability Indices for each of the three dimensions. It is seen that for the Economic, Social and Environmental indices, both AHP and PROMETHEE, convey the same result, namely that from an economic sustainability point of view, furniture making is the first placed alternative by a reasonably large margin, and it is also the leading alternative from a social sustainability point of view, though by a smaller margin. It is also agreed between AHP and PROMETHEE that, from an environmental point of view, bridge fabrication has a substantial lead on furniture making. It is clear that the third, fourth and fifth best choices are always co-processing, incineration and landfill.

Panels $\mathrm{c}$ and $\mathrm{d}$ of Fig. 3 display the integrated AHP and PROMETHEE indices, again there is unanimity between these two MCDA methods. Due to the particularly large weight on the environment compared with the other two dimensions, bridge fabrication has a small lead on furniture making. The factors which may affect these relative positions will be examined in some detail in the Sensitivity Analysis in Section 3.3. Again, there is agreement between AHP and PROMETHEE on the third, fourth and fifth ranking positions (co-processing, incineration and landfill). 
There is agreement between the ELECTRE Economy rankings and those of AHP and PROMETEE. ELECTRE results for Society placed bridge fabrication in first place with furniture making in second place, this does not agree with the AHP (and PROMETHEE) score of 0.94 (and 0.51 ) for furniture making and 0.91 (and 0.48 ) for bridge fabrication (see Fig. 3), however it is clear from these numbers that there is little difference between these two alternatives. ELECTRE was unable to distinguish between first and second place in its Environmental sustainability index, but in common with Economy and Society, it placed co-processing, incineration and landfill in 3rd, 4th and 5th places in agreement with the other two MCDA methods.

\subsection{Sensitivity analysis}

Sensitivity testing is important for an assessment of complex systems. In this case where a combination of qualitative and quantitative information has been combined, such testing acts to assure the quality of the results and the reliability of the conclusions (Walker et al., 2003; Refsgaard et al., 2007; Liu et al., 2011; Chen et al., 2013). The one at a time (OAT) method is used in order to precisely identify which of the many variables are most important for the results (Flores-Alsina et al., 2012; Chen et al., 2013). For brevity the focus will be on any change to the ranked places of the AHP integrated index. As explained in Fig. 2: . and

Fig. 3, the most sustainable end-of-life alternatives are, 1st place to bridge fabrication, 2nd to furniture making, 3rd to co-processing, 4th to incineration and 5th to landfill. The following are varied and the sustainability indices are recalculated:

i Variations to Delphi Study participant selection: One, two and three participants were omitted from the Delphi Study producing 13, 78 and 286 new scenarios. There were no changes to the ranking sequence for any of the 13 scenarios where there was one omission, the first and second places swapped for $14 \%$ of the two person omissions and $18 \%$ of the three person omissions. None of the 3rd, 4 th or 5 th places changed.

ii Variations to weights: The 11 input metrics' weights and the three dimensions' weights were varied by a range of values from $-20 \%$ to $+40 \%$, accompanied by an equally shared opposite change in the other metrics. These variations resulted in first place going to furniture making and second to bridge fabrication for 15 of the 168 variations. For example, if the weight of Eco Quality is increased from $26 \%$ to $36 \%$, (with $3.33 \%$ decreases to the other three Environmental metrics) then first place goes to furniture making instead of bridge fabrication. The sensitivity to weights is visualised below in the ternary plot (Fig. 4), which illustrates the weight combinations D and E from Table 4, panel A.

iii Variations to input metric values: The 55 input metric values, in Table 1, were each multiplied by a wide range of values from zero to one thousand in order to find factors which would bring about a change in the results. For example, when the value of Hours of Work for furniture making was multiplied by 2.2 or more, i.e. varying it from 19.2 to more than 42.2 , then furniture making took first place instead of bridge fabrication. There were changes for 15 of the 55 metrics, two of which involved factors greater than 10, and only one of which swapped 3rd (co-processing) and 4th (incineration) places. This sensitivity test shows that Community Support, Accident Rate, and Human Health are quite important in determining the outcome of the integrated index, because these can swap the first and second places when multiplied by a number bigger than 2 (or less than 0.5 ). Note that most of the changes to first and second places are a direct result of changes to their own metrics with the exception of $G H G$ which has the largest generalized weight of all the metrics. Only a huge factor of more than 270 to Human Health changes any other placings, see Table 4, panel B. iv Variations to hierarchy structure: The PROMETHEE indices were recalculated with a single level hierarchy using the generalized weights, there were no changes to the placings.

v Variations to some modelling assumptions: If co-processing were to happen in Ireland rather than Germany, there would be no changes to the placings. If the assumption of furniture end-of-life being in landfill was varied to, more than $37 \%$ of the furniture going to coprocessing, then first and second places changed.

\subsection{Ternary plot}

In order to illustrate the effect of different combinations of metrics, a ternary plot in Fig. 4 is used, (for more details see Online Supplementary Files). The combination of weights $\left(w_{E c o n}, w_{S o c}, w_{E n v}\right)$ for the dimensions of Economy, Society and Environment, is represented as a point which is a distance $w_{E c o n}$ perpendicularly away from the side opposite the economy vertex, and similarly for $w_{S o c}$ and $w_{E n v}$. This means that a combination of weights which has a high emphasis on Society such as point A, is close to the society vertex of the triangle. The points A and B correspond to combinations of weights where the AHP Integrated Sustainability Index for furniture making and bridge fabrication are equal, and therefore furniture making and bridge fabrication are considered equally sustainable for these combinations of weights along the line AB. Since AHP uses only linear functions, the boundary between the areas of the ternary plot where first place for sustainability goes to furniture (red zone) or bridge fabrication (purple zone) is a straight line along $\mathrm{AB}$. The point $\mathrm{C}(0.22,0.28,0.50)$ is the combination of weights as found by the Delphi Study (see Fig. 2). It is seen that in relation to the entire triangle of possible weight combinations, $C$ is very close to the boundary. The D position, in Table 4, panel A, corresponds to an increase of $10 \%$ to the economic weight and a decrease of $5 \%$ for both social and environmental compared to position C. For D this combination of weights makes furniture making is the most sustainable alternative. The point $\mathrm{E}$ shows that if the weight for Environment decreases then furniture can be in first place. This indicates that changes to the current weights (C) for environment and economy are important for determining first place, whereas a larger change to with weight for Society is required to change the result.

As for the other three alternatives, landfill, incineration and coprocessing are consistently in 5th, 4th and 3rd positions, so that no combination of the weights results in a change in their ranking positions.

An advantage of this method of illustrating the weights it that it is clear what size and direction of a variation in the weights is required for a change in ranking positions.

\subsection{Further research directions}

In the specific application to wind turbine blades, new research is called for in several directions, first is to design blades so that they are easier to recycle whether by using different construction materials, (Hagnell and Åkermo, 2019; Wu et al., 2019) or by using a modular design which may be de-constructed more easily (Cherrington et al., 2012; Sassanelli et al., 2019). Research into the objects which can be made from blades is not confined to bridges and furniture, (Bank et al., 2018) suggest many more possible uses. Another direction for further research is to look at the repurposing possibilities for the larger blades used in offshore wind power. A different extension of this research is to compare the relative sustainability of investment opportunities. This is important because between 2018 and 2019 investment in "sustainable" businesses in the USA increased from US $\$ 5.5 \mathrm{bn}$ to US $\$ 20.6 \mathrm{bn}$ (Rozen, 2020). This is driven by the need to diversify portfolios away from investments threatened by climate change actions (Curtin et al., 2019) as well as a desire from the public to invest in sustainable businesses. There is therefore, a need to assess the sustainability of investments. This has recently been given a boost in the EU because of a defined taxonomy for sustainable activities (European Commission, 2020). 


\section{Conclusions}

This investigation has proposed a method to use the UN SDGs to select metrics to assess sustainability in a fair, objective and robust manner, and applied this method to end-of-life alternatives for wind turbine blades. These alternatives in increasing order of sustainability were landfill, incineration with heat recovery, co-processing, furniture making and bridge fabrication. Furniture making and bridge fabrication were quite close to each other in terms of the integrated sustainability indices. These indices were created using dimensions of economic, social and environmental sustainability with an integrated perspective bringing these three aspects of sustainability together. A large array of sensitivity tests were carried out showing that the results are robust to substantial changes in the inputs to the assessment.

The first conclusion is that beginning from the UN SDGs it is shown that the integrated sustainability index developed in this investigation, is in agreement with the priority order from the EU Waste Directive and the waste hierarchy from the EPA in the USA.

The second conclusion of this research is that it is possible to use the UN SDGs in a practical, robust and fair decision-making process. The use of three MCDA methods shows that the results are consistent across different methodologies. This use of a multi-layered weighting system which justifies its results with multiple MCDA methods, can be of service to the waste management industry.

The third conclusion is that there are important nuances to be found between different dimensions of sustainability and hence there is a need for an integrated approach, such as is used in this investigation.

The investigation also offers a novel consensus-consistencyconvergence stopping condition for the Delphi Study to add a degree of objectivity to the analysis of experts' opinions. The stopping conditions are specific to the combination of AHP questioning under a Delphi Study format.

As with any research there were limitations to this investigation. There was a degree of subjectivity in the opinions gathered by the Delphi Studies and the SWOT analysis for the weightings. There was also some degree of estimation inherent in the expert opinions used in the other modelling parameters, such as the R\&D price modelling. While the investigation used Irish data, the conclusions are however not specific to Ireland because a great deal of the data is not specific to the Irish context, and may be considered to be representative of the EU and probably of most industrially developed countries. As for the other possible sources of error, these were tested with an extensive sensitivity analysis which showed that the results were remarkably robust and reliable.

Given the scale of problem presented by the decommissioning of wind blades as well as many other waste and recycling challenges, there needs to be a practical method to assist in making decisions which compare the sustainability of different end-of-life choices. This assessment method may be applied to many other sustainability choices, and to the growing field of green investment and sustainable finance to assist other researchers and policy makers. The methods in this paper offer one way to help solve sustainability decision making problems.

\section{CRediT authorship contribution statement}

Peter Deeney: Conceptualization, Methodology, Software, Validation, Formal analysis, Investigation, Data curation, Writing - original draft, Writing - review \& editing, Visualization. Angela J. Nagle: Conceptualization, Data curtion, Methodology, Investigation, Writing review \& editing. Fergal Gough: Methodology, Investigation, Data curation. Heloisa Lemmertz: Methodology, Investigation, Data curation. Emma L. Delaney: Methodology, Formal analysis, Investigation, Data curation. Jennifer M. McKinley: Methodology, Formal analysis, Investigation, Data curation, Funding acquisition, Supervision. Conor Graham: Formal analysis, Investigation. Paul G. Leahy: Conceptualization, Resources, Supervision, Project administration, Funding acquisition, Writing - review \& editing. Niall P. Dunphy: Methodology, Conceptualization, Funding acquisition, Writing - review \& editing, Supervision. Gerard Mullally: Methodology, Conceptualization, Funding acquisition, Supervision.

\section{Declaration of Competing Interest}

The authors declare that they have no known competing financial interests or personal relationships that could have appeared to influence the work reported in this paper.

\section{Acknowledgements}

This material is based upon work supported by the Re-Wind Project which has received funding from: Science Foundation Ireland, Grant 16/ US/3334; InvestNI/Department for the Economy (DFE) Grant USI-116, and U.S. National Science Foundation under Grants numbers 1701413 and 1701694. The authors would like to thank Lawrence C. Bank and the entire $R e$-Wind team who have helped with the research presented in this paper.

\section{Supplementary materials}

Supplementary material associated with this article can be found, in the online version, at doi:10.1016/j.resconrec.2021.105642.

\section{References}

Almeida, A.T., 2007. Multicriteria decision model for outsourcing contracts selection based on utility function and ELECTRE method. Comput. Oper. Res. 34 (12), 3569-3574. https://doi.org/10.1016/j.cor.2006.01.003.

Bank, L.C., Arias, F.R., et al., 2018. Concepts for reusing composite materials from decommissioned wind turbine blades in affordable housing. Recycling 3 (1), 1-12. https://doi.org/10.3390/recycling3010003.

Bank, L.C., Chen, J., et al. (2018) Re-wind design atlas. Available at:https://www.re-w ind.info/product/2020/8/5/re-wind-releases-its-design-atlas-creative-commons-lic ense-cc-by-nc-sa-40 (Accessed: 21 September 2020).

Bank, L.C., et al., 2019. Structural analysis of FRP parts from waste wind turbine blades for building reuse applications. SEMC Cape Town. DfE, Cape Town.

Barbier, E.B., Burgess, J.C., 2017. The sustainable development goals and the systems approach to sustainability. Economics 11, 1-22. https://doi.org/10.5018/ economics-ejournal.ja.2017-28.

Edited by Beauson, J., Brøndsted, P, 2016. Wind blades: an end of life Perspecive. In: Ostachowicz, M., McGugan, W., SchroRder-Hinrichs, J-U, M., Luczak (Eds.), MAREWINT: New Materials and Reliability in Offshore Wind Turbine Technology. Springer, Switzerland. https://doi.org/10.1007/978-3-319-39095-6. Edited by.

Beauson, J., et al., 2016. Recycling of shredded composites from wind turbine blades in new thermoset polymer composites. Compos. Part A: Appl. Sci. Manuf. Elsevier Ltd 90, 390-399. https://doi.org/10.1016/j.compositesa.2016.07.009.

Behzadian, M., et al., 2010. PROMETHEE: a comprehensive literature review on methodologies and applications. Eur. J. Oper. Res.. Elsevier B.V. 200 (1), 198-215. https://doi.org/10.1016/j.ejor.2009.01.021.

Bladesign (2020) Furniture design. Available at: https://www.bladesign.de/ (Accessed: 27 July 2020).

Brans, J.P., Mareschal, B., Vincke, P., 1984. PROMETHEE: a new family of outranking methods in multicriteria analysis. In: Brans, J.P. (Ed.), Operational Research. NorthHolland, Amsterdam.

Brans, J.P., Vincke, P., 1985. A preference ranking organisation method. Manage Sci 31 (6), 647-656. https://doi.org/10.1287/mnsc.31.6.647.

Cassimon, D., Engelen, P.J., Yordanov, V., 2011. Compound real option valuation with phase-specific volatility: a multi-phase mobile payments case study. Technovation 31 (5-6), 240-255. https://doi.org/10.1016/j.technovation.2010.12.004.

Chang, N.Bin, Parvathinathan, G., Breeden, J.B, 2008. Combining GIS with fuzzy multicriteria decision-making for landfill siting in a fast-growing urban region. J. Environ. Manage. 87 (1), 139-153. https://doi.org/10.1016/j. jenvman.2007.01.011.

Chen, Y., Yu, J., Khan, S., 2013. The spatial framework for weight sensitivity analysis in AHP-based multi-criteria decision making. Environ. Modell. Softw. 48, 129-140. https://doi.org/10.1016/j.envsoft.2013.06.010.

Cherrington, R., et al., 2012. Producer responsibility: defining the incentive for recycling composite wind turbine blades in Europe', Energy Policy. Elsevier 47 (2012), 13-21. https://doi.org/10.1016/j.enpol.2012.03.076.

Chiesura, G., Stecher, H., Pagh Jensen, J., 2020. Blade materials selection influence on sustainability: a case study through LCA. IOP Conf. Ser.: Mater. Sci. Eng. 942 (1) https://doi.org/10.1088/1757-899X/942/1/012011.

Clark, C.M.A., Kavanagh, C., Lenihan, N, 2020. Measuring progress: the sustainable progress index 2020. Soc. Justic. Ireland 80. 
Coelho Junior, M.G., et al., 2020. Improving the management effectiveness and decisionmaking by stakeholders' perspectives: a case study in a protected area from the Brazilian Atlantic Forest. J. Environ. Manage. 272 (November 2019), 111083 https://doi.org/10.1016/j.jenvman.2020.111083.

Cooperman, A., Eberle, A., Lantz, E., 2021. Wind turbine blade material in the United States: quantities, costs, and end-of-life options. Resour. Conservat. Recycl. Elsev. B. V. 168 (November 2020), 1-10. https://doi.org/10.1016/j.resconrec.2021.105439.

Costanza, R., et al., 2016. Modelling and measuring sustainable wellbeing in connection with the UN Sustainable Development Goals. Ecol. Econ. 130, 350-355. https://doi. org/10.1016/j.ecolecon.2016.07.009.

Cowell, R., Bristow, G., Munday, M., 2011. Acceptance,acceptability and environmenta justice:the role of community benefits in wind energy development. J. Environ. Plann. Manag. 54 (4), 539-557. https://doi.org/10.1080/09640568.2010.521047.

CSO, 2020a. Earnings and Labour Costs Quarterly: Q4 2019 (Final) Q1 2020 (Preliminary Estimates). Central Statistics Office (Ireland). Available at: https //www.cso.ie/en/releasesandpublications/er/elcq/earningsandlabourcosts q42019finalq12020preliminaryestimates/ (Accessed: 1 June 2020).

CSO, 2020b. EB049: Population Aged 15 Years and Over in the Labour Force 2011 to 2016 by County and City, Detailed Occupational Group and CensusYear. Central Statistics Office (Ireland). Available at: https://statbank.cso.ie/px/pxeirestat/Statire /SelectVarVal/Define.asp? maintable=EB049\&PLanguage $=0$ (Accessed: 1 June 2020).

Curtin, J., et al., 2019. Quantifying stranding risk for fossil fuel assets and implications for renewable energy investment: a review of the literature. Renew. Sustain. Energy Rev. 116 https://doi.org/10.1016/j.rser.2019.109402.

DCCAE (2019) New environmental levies proposed to encourage more sustainable behaviour, Government of Ireland Press Releases. Available at: https://dccae.gov. ie/en-ie/news-and-media/press-releases/Pages/Minister-Bruton-Cracks-Down-onPlastics,-Single-Use-Cups,-Landfill-and-Takeaway-Waste.aspx (Accessed: 6 August 2020).

Deeney, P., et al., 2021. A real options based decision support tool for R\&D investment: application to CO2 recycling technology. Eur. J. Oper. Res. 289 (2), 696-711. https://doi.org/10.1016/j.ejor.2020.07.015.

Delaney, E., et al., 2021. An integrated geospatial approach for repurposing wind turbine blades. Resour., Conservat. Recycl. 170, 105601 https://doi.org/10.1016/j. resconrec.2021.105601.

Delvere, I., et al., 2019. Evaluation of polymer matrix composite waste recycling methods. Environ. Climate Technol. 23 (1), 168-187. https://doi.org/10.2478/ rtuect-2019-0012.

Diamond, I.R., et al., 2014. Defining consensus: a systematic review recommends methodologic criteria for reporting of Delphi studies. J. Clin. Epidemiol. 67 (4), 401-409. https://doi.org/10.1016/j.jclinepi.2013.12.002.

Elkington, J., 1994. Towards the sustainable corporation: win-win-win business strategies for sustainable development. Calif. Manage. Rev. 36 (2), 90-100.

EPA(Ireland), 2020. Municipal Waste Statistics for Ireland. Environmental Protection Agency. Available at: https://www.epa.ie/nationalwastestatistics/municipal/ (Accessed: 2 October 2020).

EPA(USA), 2020. Waste Management Hierarchy and Homeland Security Incidents, United States Environmental Protection Agency. Available at: https://www.epa. gov/homeland-security-waste/waste-management-hierarchy-and-homeland-securit y-incidents (Accessed: 15 December 2020).

Ergu, D., Kou, G., 2012. Questionnaire design improvement and missing item scores estimation for rapid and efficient decision making. Ann. Oper. Res. 197 (1), 5-23. https://doi.org/10.1007/s10479-011-0922-3.

European Commission, 2008. Directive 2008/98/EC on Waste (Waste Framework Directive). EU. Available at: https://ec.europa.eu/environment/waste/framework/.

European Commission, 2020. EU Taxonomy for Sustainble Activities. European Commission. Available at: https://ec.europa.eu/info/business-economy-euro/ban king-and-finance/sustainable-finance/eu-taxonomy-sustainable-activities_en.

Fernandes, B., Cunha, J., Ferreira, P., 2011. The use of real options approach in energy sector investments. Renew. Sustain. Energy Rev. 15 (9), 4491-4497. https://doi.org/ 10.1016/j.rser.2011.07.102.

Flores-Alsina, X., et al., 2012. Assessing the use of activated sludge process design guidelines in wastewater treatment plant projects: a methodology based on global sensitivity analysis. Environ. Modell. Softw. 38, 50-58. https://doi.org/10.1016/j. envsoft.2012.04.005.

Ghobadi, M., Ahmadipari, M., 2018. Environmental planning for wind power plant site selection using a fuzzy PROMETHEE-based outranking method in geographical information system. Environ. Energy Econ. Res. 2 (2), 75-87. https://doi.org/ 10.22097/eeer.2018.148760.1041.

Govindan, K., Jepsen, M.B., 2016. ELECTRE: a comprehensive literature review on methodologies and applications. Eur. J. Oper. Res. Elsevier Ltd. 250 (1), 1-29. https://doi.org/10.1016/j.ejor.2015.07.019.

Hagnell, M.K., Åkermo, M., 2019. The economic and mechanical potential of closed loop material usage and recycling of fibre-reinforced composite materials. J. Clean. Prod.. Elsevier Ltd 223, 957-968. https://doi.org/10.1016/j.jclepro.2019.03.156.

Helms, M.M., Nixon, J., 2010. Exploring SWOT analysis - where are we now?: a review of academic research from the last decade. J. Strategy Manag. 3 (3), 215-251. https://doi.org/10.1108/17554251011064837.

Herath, H.S.B., Park, C.S, 2002. Multi-stage capital investment opportunities as compound real options. Eng. Econ. 47 (1), 1-27. https://doi.org/10.1080/ 00137910208965021.

Horan, D., 2020. Enabling integrated policymaking with the sustainable development goals: an application to Ireland. Sustainability 12 (18), 5-11. https://doi.org/ $10.3390 /$ su12187800.
HSA, 2018. Summary of Workplace Injury, Illness and Fatality Statistics $2017-2018$. Health and Safety Authority of Ireland. Available at: https://www.hsa.ie/eng/ (Accessed: 23 July 2020).

Humbert, S., et al., 2015. IMPACT 2002 + : user Guide'. User Guide 21, 36. Available at: http://www.pre-sustainability.com/download/DatabaseManualMethods.pdf.

IAEG-SDGs (2016) 'Final list of proposed Sustainable Development Goal indicators', Report of the Inter-Agency and Expert Group on Sustainable Development Goal Indicators, p. Annex IV. doi: ISBN 9789241508483.

IEA, 2019a. Levelised Cost of CO2 Capture by Sector and Initial CO2 concentration, 2019. International Energy Agency. Available at: https://www.iea.org/data-and statistics/charts/levelised-cost-of-co2-capture-by-sector-and-initial-co2-concentrati on-2019 (Accessed: 9 April 2021).

IEA, 2019b. World Energy Outlook 2019. International Energy Agency. Available at: http s://www.iea.org/reports/world-energy-outlook-2019.

IRENA, 2019. Future of Wind: Deployment, investment, technology, Grid Integration and Socio-Economic Aspects. International Renewable Energy Agency (IRENA). Available at: https://www.irena.org/documentdownloads/publications/re_technolo gies_cost_analysis-hydropower.pdf.

Jacob, A., 2011. Composites can be recycled. Reinforced Plastics 55 (3), 45-46. https:// doi.org/10.1016/S0034-3617(11)70079-0.

Jayaraman, R., et al., 2015. Multi-criteria model for sustainable development using goal programming applied to the United Arab Emirates. Energy Policy 87, 447-454. https://doi.org/10.1016/j.enpol.2015.09.027.

Jensen, J.P., Skelton, K., 2018. Wind turbine blade recycling: experiences, challenges and possibilities in a circular economy. Renew. Sustain. Energy Rev. Elsevier Ltd 97 (October 2017), 165-176. https://doi.org/10.1016/j.rser.2018.08.041.

Joustra, J., Flipsen, B., Balkenende, R., 2021. Structural reuse of high end composite products: a design case study on wind turbine blades. Resour., Conservat. Recycl. Elsevier B.V. 167 (January) https://doi.org/10.1016/j.resconrec.2020.105393.

Kendall, M.G., Smith, B.B., 1939. The problem of m rankings. Annal. Math. Stat. 10 (3), 275-287. https://doi.org/10.1214/aoms/1177732186.

Kim, M., Jang, Y.C., Lee, S., 2013. Application of Delphi-AHP methods to select the priorities of WEEE for recycling in a waste management decision-making tool. J. Environ. Manag.. Elsevier Ltd 128, 941-948. https://doi.org/10.1016/j. jenvman.2013.06.049.

Lefeuvre, A., et al., 2019. Anticipating in-use stocks of carbon fibre reinforced polymers and related waste generated by the wind power sector until 2050. Resour., Conservat. Recycl. Elsevier 141 (April 2018), 30-39. https://doi.org/10.1016/j. resconrec.2018.10.008.

Lin, C., Kou, G., Ergu, D, 2013. An improved statistical approach for consistency test in AHP. Ann. Oper. Res. 211 (1), 289-299. https://doi.org/10.1007/s10479-013-14135.

Liu, K.F.R., et al., 2011. Hierarchical analytic network process and its application. Civil Eng. Environ. Syst. 28 (1), 1-18.

Liu, P., Meng, F., Barlow, C.Y., 2019. Wind turbine blade end-of-life options: an eco-audit comparison. J. Clean. Prod. 212, 1268-1281. https://doi.org/10.1016/J. JCLEPRO.2018.12.043.

Mardani, A., et al., 2015. Sustainable and renewable Energy: an overview of the application of multiple criteria decision making techniques and approaches. Sustainability (Switzerland) 7 (10), 13947-13984. https://doi.org/10.3390/ su71013947.

Miljøskærm (2020) Recycling of fiberglass /composite materials. Available at: http://mil joskarm.dk/english/.

Murray, R.E., et al., 2021. Structural validation of a thermoplastic composite wind turbine blade with comparison to a thermoset composite blade. Renew. Energy. Elsevier Ltd 164, 1100-1107. https://doi.org/10.1016/j.renene.2020.10.040.

Nagle, A.J., Bank, L.C., Delaney, E. and Leahy, P.G. (2020) 'A comparative life cycle assessment between landfilling and co-processing of waste from decommissioned Irish wind turbine blades', J. Clean. Prod.

NISRA, 2015. Review of Statistical Classification and Delineation of Settlements. Northern Ireland Statistics and Research Agency (March). Available at: http s://www.nisra.gov.uk/sites/nisra.gov.uk/files/publications/review-of-the-statist cal-classification-and-delineation-of-settlements-march-2015\%281\%29.pdf.

Park, K.S., et al., 2020. A new method for estimating human error probabilities: AHPSLIM'. Resour., Conservat. Recycl.. Elsevier 93 (4), 578-587. https://doi.org/ 10.13140/RG.2.2.16912.02564.

Pohekar, S.D., Ramachandran, M., 2004. Application of multi-criteria decision making to sustainable energy planning - a review. Renew. Sustain. Energy Rev. 8 (4), 365-381. https://doi.org/10.1016/j.rser.2003.12.007.

Refsgaard, J.C., et al., 2007. Uncertainty in the environmental modelling process - a framework and guidance. Environ. Modell. Softw. 22 (11), 1543-1556. https://doi. org $/ 10.1016 /$ j.envsoft.2007.02.004

Revez, A., et al., 2020. Beyond forecasting: using a modified delphi method to build upon participatory action research in developing principles for a just and inclusive energy transition. Int. J. Qual. Methods 19, 1-12. https://doi.org/10.1177/ 1609406920903218 .

Rogers, J.C., et al., 2008. Public perceptions of opportunities for community-based renewable energy projects. Energy Policy 36 (11), 4217-4226. https://doi.org/ 10.1016/j.enpol.2008.07.028.

Roy, B., 1968. Classement et choix en présence de points de vue multiples. Revue française d'informatique et de recherche opérationnelle 2 (8), 57-75. https://doi. org/10.1051/ro/196802v100571.

Rozen, M., 2020. Ethical Investors Want More Proof of Good deeds: Clients and Advisers Push for Tougher Validation of Data. Financial Times, p. 16th April 2020. Available at: https://www.ft.com/content/5c943b66-5a22-11ea-abe5-8e03987b7b20?deskt 
op=true\&segmentId=7c8f09b9-9b61-4fbb-9430-9208a9e233c8\#myft:notification: daily-email:content.

Saaty, T.L., 2002. Decision making with the analytic hierarchy process. Scientia Iranica 9 (3), 215-229. https://doi.org/10.1504/ijssci.2008.017590.

Saaty, T.L., 2008. Decision making with the analytic hierarchy process. Int. J. Serv. Sci. 1 (1), 83-98.

Sassanelli, C., et al., 2019. Circular economy performance assessment methods: a systematic literature review. J. Clean. Prod. 229, 440-453. https://doi.org/10.1016/ j.jclepro.2019.05.019.

Scherer, L., et al., 2018. Trade-offs between social and environmental sustainable development goals. Environ. Sci. Policy 90 (September), 65-72. https://doi.org/ 10.1016/j.envsci.2018.10.002.

Van Schoubroeck, S., et al., 2019. Sustainability indicators for biobased chemicals: a Delphi study using multi-criteria decision analysis. Resour., Conservat. Recycl. Elsevier 144 (December 2018), 198-208. https://doi.org/10.1016/j. resconrec.2018.12.024.

SEAI, 2021. Wind Energy. Sustainable Energy Authority of Ireland. Available at: htt ps://www.seai.ie/technologies/wind-energy/\#: : text=In2018Windprovide d85,2018\%2CafterDenmarkandUruguay (Accessed: 1 January 2021).

Strantzali, E., Aravossis, K., 2016. Decision making in renewable energy investments: a review. Renew. Sustain. Energy Rev. 55, 885-898. https://doi.org/10.1016/j. rser.2015.11.021. Elsevier.

Suhail, R., et al., 2019. Analysis and design of a pedestrian bridge with decommissioned FRP Windblades and Concrete. 14th International Symposium on Fiber-Reinforced Polymer Reinforcement of Concrete Structures (FRPRCS). Belfast, Northern Ireland, UK.

SuperUse (2020) Playground Wikado. Available at: https://www.superuse-studios. com/projects/wikado/ (Accessed: 1 October 2020).

Sustainability, P., 2019. LCA Software and Database Manual. SimaPro 9, Berlin, Germany. Available at: https://www.presustainability.com/sustainability-consultin $\mathrm{g} /$ sustainable-practices/customsustainability-software.

Tazi, N., et al., 2019. Waste and material flow analysis in the end-of-life wind energy system. Resour., Conservat. Recycl.. Elsevier 145 (October 2018), 199-207. https:// doi.org/10.1016/j.resconrec.2019.02.039.

Tugrul, B., Cimen, S., 2016. Importance of corporate governance for energy in sustainable development and evaluation with quantitative SWOT analysis. Acta Physica Polonica A 130 (1), 87-89. https://doi.org/10.12693/APhysPolA.130.87.

UN, 2015. Transforming Our World: The 2030 Agenda for Sustainable Development. UN. https://doi.org/10.1201/b20466-7.

Vavatsikos, A.P., Demesouka, O.E., Anagnostopoulos, K.P., 2020. GIS-based suitability analysis using fuzzy PROMETHEE. J. Environ. Plann. Manag. 63 (4), 604-628. https://doi.org/10.1080/09640568.2019.1599830.
Walker, W.E., et al., 2003. Defining uncertainty: a conceptual basis for uncertainty management in model-based decision support. Integrat. Assessment 4 (1), 5-17. https://doi.org/10.1076/iaij.4.1.5.16466.

Wang, X., Triantaphyllou, E., 2008. Ranking irregularities when evaluating alternatives by using some ELECTRE methods. Omega (Westport) 36 (1), 45-63. https://doi.org/ 10.1016/j.omega.2005.12.003.

Webber, A., 2020. The "green team" Turning Disused Wind Turbines Into Stylish Street and Garden Furniture. The first News. Available at: https://www.thefirstnews.com/ article/the-green-team-turning-disused-wind-turbines-into-stylish-street-and-garden -furniture-10543.

Wernet, G., et al., 2016. The ecoinvent database version 3 (part I): overview and methodology. Int. J. Life Cycle Assess. Int. J. Life Cycle Assess. 21 (9), 1218-1230. https://doi.org/10.1007/s11367-016-1087-8.

Wesseh, P.K., Lin, B., 2015. Renewable energy technologies as beacon of cleaner production: a real options valuation analysis for Liberia. J. Clean. Prod. 90, 300-310. https://doi.org/10.1016/j.jclepro.2014.11.062.

Winddemark (2019) Decommissioned wind turbine blades becomes noise barriers. Available at: https://en.winddenmark.dk/news/decommissioned-wind-turbineblades-becomes-noise-barriers (Accessed: 1 October 2020).

WindEurope (2020) 'Accelerating wind turbine blade circularity', (May).

WindEurope (2021) Wind energy in Europe in 2019 trends and statistics. Available at: https://windeurope.org/data-and-analysis/product/wind-energy-in-europe-in2019-trends-and-statistics/ (Accessed: 1 January 2021).

Wu, M.S., et al., 2019. A recyclable epoxy for composite wind turbine blades. Adv. Manuf. 5 (3), 114-127. https://doi.org/10.1080/20550340.2019.1639967.

WWEA (2021) World wind capacity. Available at: https://wwindea.org/world-wind-ca pacity-at-650-gw/ (Accessed: 29 January 2021).

Yazdanbakhsh, A., et al., 2018. Concrete with discrete slender elements from mechanically recycled wind turbine blades. Resour., Conservat. Recycl. 128 (August 2017), 11-21. https://doi.org/10.1016/j.resconrec.2017.08.005.

Yusof, N., Ishak, S.S.M., Doheim, R, 2018. Identifying factors for incorporating spatial data into BIM using the delphi method. Construct. Econ. Build. 18 (3), 1-17. https:// doi.org/10.5130/AJCEB.v18i3.6031.

Zanakis, S.H., et al., 1998. Multi-attribute decision making: a simulation comparison of select methods. Eur. J. Oper. Res. 107 (3), 507-529. https://doi.org/10.1016/ S0377-2217(97)00147-1.

Zavadskas, E.K., et al., 2018. A novel multicriteria approach - rough step-wise weight assessment ratio analysis method (R-SWARA) and its application in logistics. Stud. Inf. Control 27 (1), 97-106. https://doi.org/10.24846/v27i1y201810. 